\title{
Linking fish and prawns to their environment: a hierarchical landscape approach
}

\author{
S. J. Pittman ${ }^{1,3, *}$, C. A. McAlpine ${ }^{1}$, K. M. Pittman ${ }^{2}$ \\ ${ }^{1}$ School of Geography, Planning and Architecture and The Ecology Centre, The University of Queensland, \\ Brisbane 4072, Australia \\ ${ }^{2}$ Springfield, Mingle Lane, Cambridge, UK \\ ${ }^{3}$ Present address: NOAA/NOS/CCMA Biogeography Program, 1305 East-West Highway, Silver Spring, Maryland 20910, USA
}

\begin{abstract}
Little is known about the relative influence of landscape structure on the spatial distribution and abundance of marine organisms. To address this problem, we applied landscape ecology concepts and methods, together with conventional sampling techniques and path analysis, to test alternative hypotheses of linkages between marine nekton and landscape structure in Moreton Bay, Queensland (Australia). We quantified substratum structure at 3 spatial scales: (1) whole landscape mosaic (10s of hectares); (2) habitat type (benthic class) (100s $\mathrm{m}^{2}$ to hectares) and (3) within-patch scale $\left(\mathrm{cm}^{2}\right.$ to $\left.\mathrm{m}^{2}\right)$. Substratum structure at all scales was important for assemblage density and number of species, with the landscape structure of individual habitat types explaining more of the spatial variation than either within-patch structure or the structure of the whole landscape mosaic. Density and the number of species of seagrass residents were strongly influenced by landscape composition quantified as the proportion of all seagrass habitat $\left(\mathrm{r}^{2}=0.40\right.$ and 0.48 respectively) and the proportion of long-leaved Zostera capricorni $\left(\mathrm{r}^{2}=0.34\right.$ and 0.30 respectively) seagrass in the landscape. An abrupt decline in assemblage density and number of species was evident at $<20 \%$ seagrass cover. More species of fish used mangroves with adjacent continuous seagrass beds than mangroves with adjacent patchy seagrasses or unvegetated sandflats. Several species of fish using mangroves at high tide were more strongly influenced by the spatial configuration of mangrove patches and the composition of adjacent substratum than the internal structure of mangrove patches. The study highlights the need for a hierarchical landscape approach when investigating animal-environment relations in marine landscapes.
\end{abstract}

KEY WORDS: Marine landscape ecology · Landscape structure - Spatial scale $\cdot$ Hierarchy $\cdot$ Fish Penaeid prawns $\cdot$ Mangroves $\cdot$ Seagrass $\cdot$ Path analysis

Resale or republication not permitted without written consent of the publisher

\section{INTRODUCTION}

Increasingly, ecologists acknowledge that a wide range of interacting environmental patterns and processes operating at multiple scales determine species distribution and abundance (Ricklefs 1987, Urban et al. 1987, Allen \& Hoekstra 1992, Holling 1992, Schneider 2001, Cushman \& McGarigal 2002, Lee et al. 2002, Grand \& Cushman 2003) and that most species (and even different life stages) experience and respond to the environment differently and at their own unique set of spatial and temporal scales (Morris 1987, Wiens
\& Milne 1989, Holling 1992, Levin 1992, Wiens 1995). To address this complexity, it is necessary to develop conceptual and analytical frameworks that recognise the need to study ecological phenomena from a multiscaled hierarchical perspective (Allen \& Starr 1982, Kotliar \& Wiens 1990, Allen \& Hoekstra 1992, Holling 1992, McAlpine et al. 1999, Mackey \& Lindenmayer 2001, Lee et al. 2002, Pittman \& McAlpine 2003). Such frameworks also need to incorporate environmental heterogeneity at scales that are ecologically meaningful to the species of interest, and this requires an explicit consideration of the spatial and temporal movement 
patterns of individual organisms (Addicott et al. 1987, Morris 1987, Wiens \& Milne 1989, Holling 1992, Sale 1998, Pittman \& McAlpine 2003).

Landscape ecology theory and methods have been developed to investigate the linkages between ecological patterns and processes at meaningful spatial and temporal scales (Turner 1989, Wiens \& Milne 1989, Pearson 1993). Two key lines of enquiry in the landscape approach to animal-environment relationships are: (1) to determine the spatial scales at which physical structure in the landscape are most influential (e.g. McGarigal \& McComb 1995, Lee et al. 2002) and (2) to determine the relative importance of landscape composition versus landscape configuration that can affect ecological processes independently and in combination (e.g. Fahrig 1997, 2003, Villard et al. 1999). For many terrestrial species and assemblages, landscape composition represented by area of suitable habitat type, is more influential than landscape spatial configuration (McGarigal \& McComb 1995, Fahrig 1997, 2003, Trzcinski et al. 1999, Villard et al. 1999, Lee et al. 2002, McAlpine \& Eyre 2002, Schmiegelow \& Mönkkönen 2002). Landscape composition encompasses the variety and abundance of habitat types. Landscape configuration (or spatial pattern) is the physical distribution of patches and is measured by the quantification of geometric and spatial properties of categorical maps, including shape, area, amount of edge, patch isolation and contagion (McGarigal \& Marks 1994, HainesYoung \& Chopping 1996, Gustafson 1998, Hargis et al. 1998). Studies of habitat fragmentation have shown that landscape configuration only becomes significant at low levels of suitable habitat area, with different species disappearing at different points (thresholds) on the habitat-loss gradient (Andrén 1994, With \& Crist 1995, Fahrig 2002). A decrease in habitat cover and a simultaneous increase in fragmentation results in species-specific constraints on movement, energetics and survival and, in turn, influences patterns of spatial distribution and abundance. In terrestrial systems, a landscape approach now underpins many strategies for species and habitat conservation, landscape restoration and natural resource management (Lui \& Taylor 2002).

However, a landscape approach to the ecological study of marine animals is still in its infancy (Kneib 1994, Robbins \& Bell 1994, Garrabou et al. 1998, Eggleston 1999, Pittman \& McAlpine 2003), with few studies quantifying marine landscape structure at scales appropriate to the spatial patterns of habitat use. Investigations have been dominated by studies in single habitat types, particularly seagrass beds, and often with landscape units selected at arbitrary scales (reviewed by Pittman \& McAlpine 2003), which have yielded equivocal results regarding the relative importance of marine landscape structure. In North Car- olina, USA, Irlandi (1994) and Irlandi et al. (1995) concluded that the landscape composition and configuration of seagrass beds $(10 \times 10 \mathrm{~m}$ plots $)$, as well as the structural characteristics of the seagrasses (shoot density) influenced the foraging success of predatory fish and crabs. In New Zealand, Turner et al. (1999) found that landscape configuration (fractal dimension and nearest neighbour distance) of seagrass beds (2 to $3 \mathrm{~km}^{2}$ ) was the strongest predictor of variation in species abundance for benthic macrofauna. In contrast, Hovel et al. (2002), working in North Carolina, found that within $50 \times 50 \mathrm{~m}$ plots, seagrass biomass and relative exposure (REI) explained substantially more variation in fish and crab density than did measures of landscape composition (\% cover) or configuration (total linear edge). In the Philippines, Salita et al. (2003) selected $10 \times 10 \mathrm{~m}$ plots, and found that neither landscape composition (\% seagrass cover) nor configuration (fractal dimension, mean patch size, patch shape) adequately explained the observed variation in fish density. For highly mobile species, particularly those species that use $>1$ habitat type through daily home range movements or ontogenetic shifts, a broader scale approach that incorporates multiple habitat types may be more appropriate (Ogden \& Gladfelter 1983, Birkeland 1985, Parrish 1989, Irlandi \& Crawford 1997, Marguillier et al. 1997, Nagelkerken et al. 2001, Cocheret de la Morinière et al. 2003, Gillanders et al. 2003, Mumby et al. 2004).

This paper investigates the linkages between marine landscape structure and the spatial distributions and abundance of juvenile fish and penaeid prawns using vegetated inshore areas of Moreton Bay, Queensland (Australia). We apply a hierarchical landscape approach to capture and analyse data, with the objective of determining the relative importance to fish and prawns of: (1) the composition and spatial configuration of the whole landscape mosaic (10s of hectares) and of individual habitat types (benthic class) (100s m² to hectares) and (2) the within-patch habitat structure $\left(\mathrm{cm}^{2}\right.$ to $\left.\mathrm{m}^{2}\right)$. We conceptualise marine landscape structure as a spatial hierarchy (Allen \& Starr 1982, O'Neill 1986, Urban et al. 1987) of components forming habitat mosaics (see Pittman \& McAlpine 2003 for details, and also examples by Kneib 1994, Robbins \& Bell 1994, Attrill et al. 2000, Schneider 2001). At the finest, scales (cm) are the within-patch structural attributes of the substratum such as plant morphology, species composition and the structure of surficial sediments. At the broadest scales $(100 \mathrm{~s} \mathrm{~m})$, relevant to the daily tidal excursions of many species, are the structural variables of landscape composition and spatial configuration.

Alternative hypotheses were constructed to determine the relative importance of landscape and withinpatch substratum variables for assemblage density 
(density of all species pooled), number of species and for density of individual species. The approach differs from the traditional null hypothesis testing of single and separable causation, which is essentially experimental and reductionist in character (sensu Holling 1998). Rather, we adopted an integrative approach, whereby multiple and only partially separable causes were tested using multiple, competing alternative hypotheses extending over multiple spatial scales.

\section{MATERIALS AND METHODS}

Study area. Deception Bay is a shallow water embayment within Moreton Bay, south-east Queensland, Australia (Fig. 1). Sampling took place in northern Deception Bay, an extensive beach/tidal flat (intertidal of 500 to $900 \mathrm{~m}$, with a gradient of $0.0018^{\circ}$ ) experiencing a semi-diurnal tidal cycle (tidal range 1.7 to $2 \mathrm{~m}$ ) and characterised by complex spatial patterns of sediment and aquatic vegetation. Grain sizes of surficial sediments vary from coarse quartz sands to fine prodelta muds. The upper intertidal supports fringing mangroves dominated by Avicennia marina ssp. australasica, which are immersed for up to $5 \mathrm{~h}$ on the highest tides of the year (maximum water depth of $1.5 \mathrm{~m}$ ). Adjacent tidal flats support mixed-species communities of seagrasses and macroalgae, dominated by Zostera capricorni. A gradient in seagrass coverage exists, from continuous beds in low-energy areas to patchy

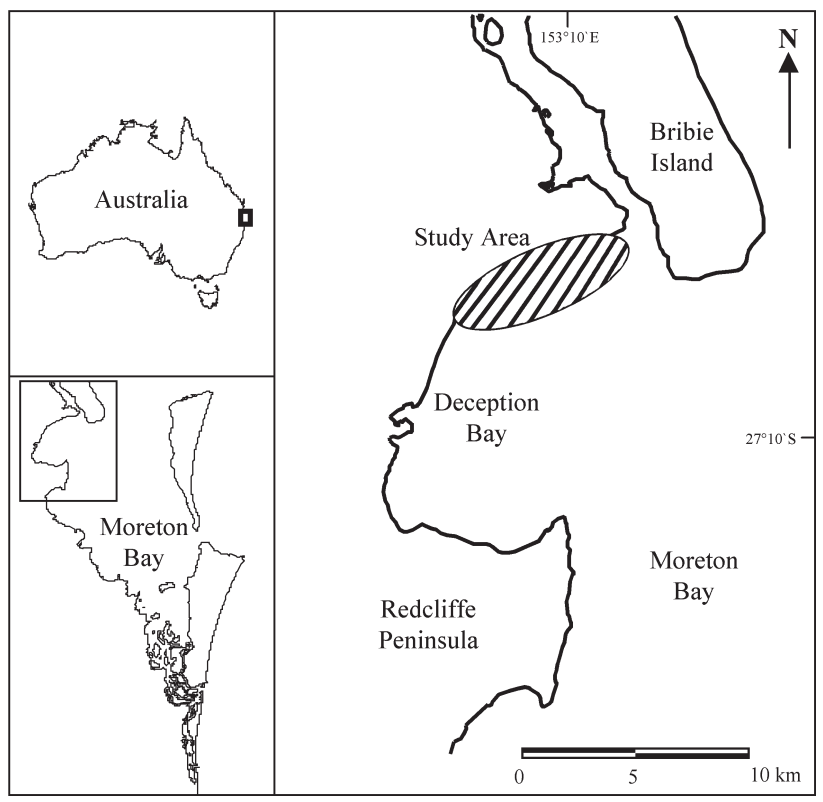

Fig. 1. Study area of northern Deception Bay located within Moreton Bay, south-east Queensland, Australia beds in higher energy areas. Where exposure is greatest, a highly mobile ridge and runnel topography is present.

Sampling fish and prawns. The temporal extent of this study (October 1999 to May 2000) was selected to include the period of peak summer (October to February) recruitment to shallow inshore areas for many fish and decapod crustaceans in Moreton Bay. The spatial extent of the study area was based on an estimate of the maximum distance that fish and prawns moved during daily tidal excursions from the shallow subtidal at low tide to the upper intertidal (i.e. the daily home range). Underwater observations suggested that juvenile fish were concentrating in shallow subtidal waters ( $<3 \mathrm{~m}$ depth) at low tide and then moving shoreward with the flooding tide.

A spatially stratified random sampling strategy was designed to sample assemblages of small-bodied $(<25 \mathrm{~cm})$ epibenthic and demersal fish and penaeid prawns. Intertidal areas were stratified into mangroves and adjacent tidal flats, which allowed animals to be sampled in a way that was appropriate for each stratum. The shallow subtidal zone also was sampled at low tide. A large $\left(16 \mathrm{~m}^{2}\right)$ remote-release buoyant pop net with demonstrated high-capture and -recovery efficiency (Serafy et al. 1988, Connolly 1994) was used to sample within mangroves at daytime high tide (water depths of 0.20 to $1.35 \mathrm{~m}$ ). Durable polyethylene shade cloth (1 $\mathrm{mm}$ aperture) formed the walls of the net, with a float-line constructed of $4 \times 4 \mathrm{~m}$ lengths of plastic electrical conduit pipe sealed at the ends with a polymer epoxy resin to ensure positive buoyancy. The apparatus was floorless to permit fish and crustaceans to perform normal behavioural interactions with the substratum. Nets were set up at low tide by burying the sink line (leaded rope) into the sediment and securing with steel tent pegs, placed through brass eyelets at $50 \mathrm{~cm}$ intervals. The net was gathered together under the pipes and weighted down with 4 small $(10 \times 20 \mathrm{~cm})$ sand bags attached by thin nylon cord to a wooden stake positioned approximately $20 \mathrm{~m}$ away from the net. At high tide, nets were released remotely by pulling on the cords. The float-line surfaced in 2 to $3 \mathrm{~s}$ and was hoisted up onto stakes to prevent fish escaping. All animals were collected from residual water with a dip net 2 to $3 \mathrm{~h}$ after high tide, and the enclosure was checked again when all water had drained away.

A small iron beam trawl (1 $\mathrm{m}$ wide and $0.5 \mathrm{~m}$ high), with a $2 \mathrm{~mm}$ net aperture, was used to sample the tidal flats seaward of the mangrove fringe at high tide and subtidal waters at low tide (water depth of 0.60 to $3.5 \mathrm{~m}$ ). Beam trawling is effective for catching a wide range of seagrass-associated species (Harmelin-Vivien \& Francour 1992, McNeill \& Bell 1992). Tow-paths of 
$50 \mathrm{~m}$ parallel to the shoreline were trawled at approximately $1 \mathrm{~m} \mathrm{~s}^{-1}$, providing a basal sample unit area of $50 \mathrm{~m}^{2}$. A total of 401 random samples were collected across northern Deception Bay (139 mangroves, 226 intertidal flats and 36 subtidal) encompassing a total benthic basal area of $17.3 \mathrm{~km}^{2}$. The positions of trawl paths and pop-net samples were recorded using a handheld differential GPS receiver. Water depth, temperature, salinity and turbidity were measured at each sample location using a YSI/Grant 3800 Water Quality Datalogger.

Immediately after capture, animals were transferred into buckets of aerated seawater. Non-target animals (rays, crabs, squid and other molluscs) were immediately released, along with any detached vegetation. In the field laboratory, individuals were identified, measured (total length and carapace length), weighed $( \pm 0.01 \mathrm{~g})$ and then released on the following high tide.

Quantifying substratum structure. An integrated approach to quantifying, classifying and mapping environmental data at multiple spatial scales was developed and applied. All substratum variables measured are shown in Fig. 2. Mean leaf length, shoot density, number of plant species and percentage species composition (including macroalgae) were measured within 10-cm diameter plots across a grid of 163 georeferenced locations. Sediment grain size and the percentage composition of mud, sand and organic content

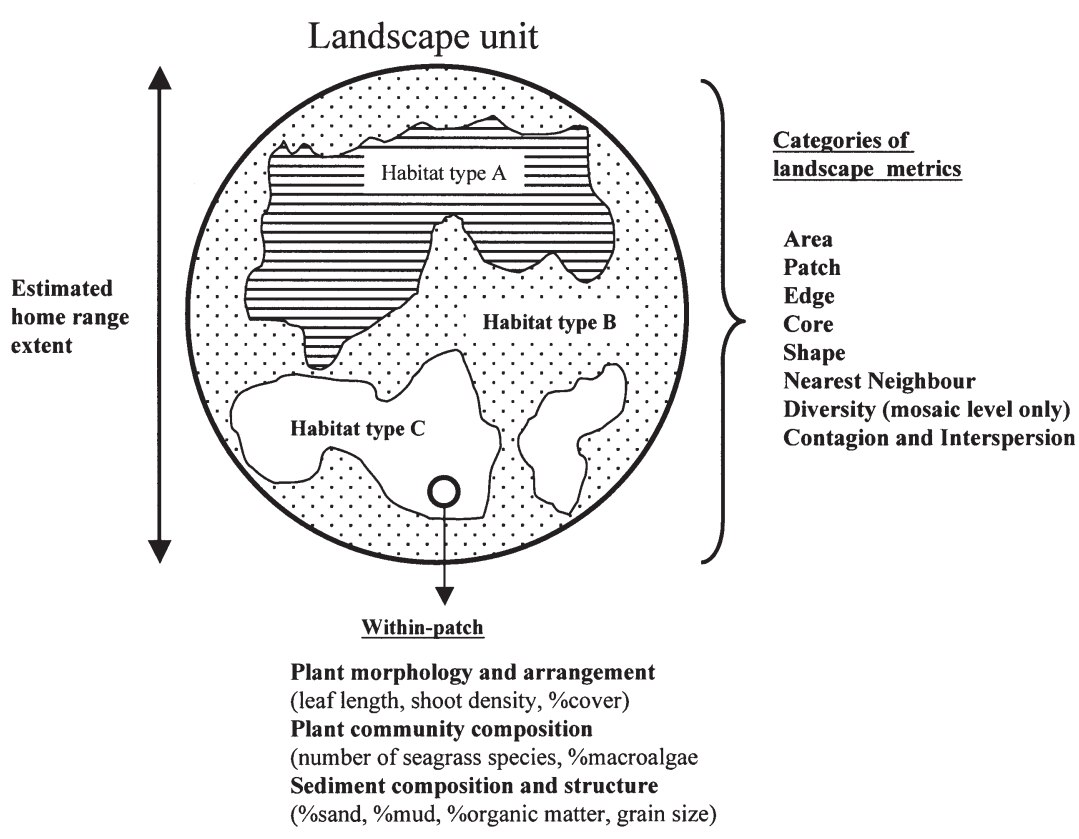

Fig. 2. Diagrammatic representation of the relationship between the 3 levels of substratum structure quantified in this study: (1) landscape mosaic structure (mosaic level); (2) structure of individual habitat types (class level), at the scale of estimated home range using landscape pattern metrics; and (3) within-patch structural variables, using benthic cores and underwater videography were quantified from a grid of 46 samples using microscopic examination. To capture spatially continuous data of vegetation cover, a digital video camera (Sony DCR-TRV900) in an underwater housing (Amphibico Inc.) was attached to an aluminium pontoon and towed along transects by boat (total transect length of $9.4 \mathrm{~km}$ ). Spatial coordinates were recorded simultaneously using a GPS receiver.

Production of a thematic habitat map: To create a map template, all patches of vegetation ( $>1 \mathrm{~m}^{2}$ ground resolution) discernible from two 1:10 000 colour aerial photograph mosaics $(35 \times 35 \mathrm{~cm}$ ground resolution) were digitised using ArcView v3.2. A classification scheme for benthic classes was constructed by using the most influential within-patch variables (plant and sediment) and applying the Bray-Curtis similarity coefficient (Bray \& Curtis 1957), followed by an agglomerative hierarchical clustering algorithm using group-average linkage (UPGMA) to form 'natural groupings' of samples (Sheppard et al. 1995, Mumby \& Harbourne 1999, Green et al. 2000). This was performed using PRIMER v5 statistical software (Plymouth Routines in Multivariate Ecological Research, 2001). In addition, Landsat Thematic Mapper data $(30 \times 30 \mathrm{~m}$ ground resolution) were acquired to provide information on the spatial distribution of the most distinct spectral classes (i.e. long-leaved Zostera capricorni) across the study area. A supervised spectral classification (guided by a set of previously identified points) and an unsupervised spectral classification (using an untrained algorithm) were performed using ERDAS Imagine v8.4. Overall map accuracy of $64 \%$ for the supervised classification and $50 \%$ for the unsupervised classification were estimated using an independent set of 30 ground samples of leaf length, shoot density, plant species composition and sediment colour (Munsell soil colour charts). Integration of the final habitat classification and delineation of class boundaries was facilitated by overlaying all spatial data (i.e. cores, videography, aerial photography and Landsat) using a GIS.

Topological irregularities and attribute accuracy were checked, and the final thematic digital map was converted from a SHAPE file into a raster GRID using ArcInfo v8. Two maps were produced in this way (Table 1): (1) a map with 11 classes representing the full range of post-classification heterogeneity to which class level metrics 
Table 1. Classification scheme for 2 categorical maps from which landscape structure was quantified, representing: (a) the full range of habitat types (11 benthic classes = low contrast/high heterogeneity) identified in northern Deception Bay and (b) a more simplified classification (4 benthic classes $=$ high contrast/low heterogeneity)

(a) Class descriptors for low-contrast map

Short leaf length $<7 \mathrm{~cm}$ (mixed species)

High cover $>40 \%$

Sand

Long leaf length $>18 \mathrm{~cm}$ (Zostera capricorni)

High cover $>90 \%$

Mud

Medium leaf length 5 to $18 \mathrm{~cm}$

(Z. capricorni and Halophila ovalis)

High cover $>40 \%$

Shelly sandy mud

Short leaf length $<7 \mathrm{~cm}$ (mixed species)

Low cover $<10 \%$

Sand

Short to medium leaf length

Highly variable cover

Sand

Mangroves (Avicennia marina dominated)

Mud to sand

Rock and rock oyster reef

Area disturbed by bait-digging

Highly variable seagrass and surficial sediment

structure

Unvegetated coarse quartz sand

Unvegetated mud and sandy mud

Unvegetated muddy sand

(b) Class descriptors for high-contrast map

Short to medium leaf length

Variable cover

Sand and muddy sand

Medium to long leaf length (Z. capricorni and H. ovalis)

High cover

Mud and shelly sandy mud

Mangroves (A. marina dominated)

Mud to sand

Unvegetated

were applied and (2) a map with 4 classes, showing only the higher contrasting heterogeneity (i.e. 2 seagrass habitat classes, 1 of mangrove and 1 unvegetated), to which landscape mosaic level metrics were applied.

Quantification of landscape composition and configuration: In order to quantify landscape structure, a 100 and $300 \mathrm{~m}$ radial buffer was applied to the centroid of each nekton sample site $(\mathrm{n}=401)$. The area contained within each extent is referred to as a landscape unit. Landscape units at each buffer distance were 'clipped' out of the digital maps, and the landscape structure for each unit quantified using FRAGSTATS v2.0 spatial pattern analysis software (McGarigal \& Marks 1994). A total of 15 landscape metrics, representing 8 key metric categories (Table 2) were initially chosen to measure composition and spatial pattern. These algorithms compute statistics for 2 levels: class and mosaic. Class level metrics represent the area (proportion of the landscape) and spatial pattern of a single habitat type within a landscape unit, while mosaic level metrics represent the spatial configuration and habitat diversity of the entire landscape unit (McGarigal \& Marks 1994). In the calculation of total core area (TCA), a narrow $(1 \mathrm{~m})$ internal edge buffer was applied, thereby ensuring that, for even relatively small patches, the interior was retained in the patch core area. To incorporate the magnitude of difference between patches, weightings were assigned to adjacent habitat classes, based on the level of ecological similarity, in order to calculate contrast-weighted edge density (CWED). FRAGSTATS requires that weights range between 0 (no contrast) and 1 (maximum contrast). We assigned highest contrast $(0.7$ to 0.85 ) to the edges between vegetated and unvegetated substrata, for example, where high biomass seagrasses were surrounded by unvegetated sand. The boundary between seagrasses and mangroves also were considered significant ( 0.5 to 0.6$)$, since many species using seagrasses were not found within mangroves. Lowest contrast was assigned to: (1) unvegetated classes that differed primarily in the relative composition of sand and mud (0.05 to 0.10); (2) sparse short-leaved seagrasses and unvegetated sand (0.10); and (3) 2 classes of dense seagrasses, differing in mean leaf length $(0.15)$

Statistical analyses. At the species level, only numerically dominant species were examined, including Pelates sexlineatus (eastern trumpeter), Centropogon australis (barred fortesque), Arenigobius frenatus (half-bridled goby) and Metapenaeus bennettae (greasyback prawn) sampled from tidal flats and Sillago spp. (whiting), Acanthropagrus australis (yellowfinned bream) and Mugilogobius stigmaticus (mangrove goby) sampled from mangroves. Data from mangroves and from adjacent intertidal and subtidal areas were transformed to approximate normality (as required for parametric statistical techniques) and analysed separately due to the differences in sampling techniques. At the within-patch level, water parameters and the structural and compositional characteristics of the substratum were examined for their association with animal density and number of species using Pearson product moment correlation (Sokal \& Rolf 1995). The strongest variables were fed into the final path analysis. In addition, relationships between nekton assemblage attributes and the proportion of individual habitat types in the landscape were investigated using linear regression on square-root transformed variables. 
Table 2. Metrics computed with FRAGSTATS software to quantify composition $\left({ }^{*}\right)$ and spatial arrangement $\left({ }^{* *}\right)$ at the level of habitat type (Class) and the landscape mosaic as a whole (Mosaic). Algorithms and descriptions of mathematical formula are provided in McGarigal \& Marks (1994)

\begin{tabular}{|c|c|c|c|}
\hline Metric & Level & Acronym & Description \\
\hline \multicolumn{4}{|l|}{ Area } \\
\hline Class area (ha) ${ }^{*}$ & Class & $\mathrm{CA}$ & Total area of all patches \\
\hline Percent of mosaic $(\%)^{*}$ & Class & $\% \mathrm{M}$ & Percentage of area occupied by each class \\
\hline Largest patch index $(\%)^{*}$ & Class/Mosaic & LPI & Percentage of area occupied by largest patch \\
\hline \multicolumn{4}{|l|}{ Patch } \\
\hline Number of patches ${ }^{* *}$ & Class/Mosaic & NP & Total number of patches \\
\hline Mean patch size $(\mathrm{ha})^{* *}$ & Class/Mosaic & MPS & Average area of all patches \\
\hline \multicolumn{4}{|l|}{ Edge } \\
\hline Total edge $(\mathrm{m})^{* *}$ & Class/Mosaic & TE & Total length of edge of all patches \\
\hline $\begin{array}{l}\text { Contrast-weighted } \\
\text { edge density }\left(\mathrm{m} \mathrm{ha}^{-1}\right)^{* *}\end{array}$ & Class/Mosaic & CWED & $\begin{array}{l}\text { Amount of edge as a function of the magnitude of } \\
\text { contrast }\end{array}$ \\
\hline \multicolumn{4}{|l|}{ Core } \\
\hline Total core area $(\mathrm{ha})^{*, * *}$ & Class/Mosaic & TCA & $\begin{array}{l}\text { Area remaining (interior) after eliminating a user- } \\
\text { defined edge width }\end{array}$ \\
\hline \multicolumn{4}{|l|}{ Shape } \\
\hline Mean patch fractal dimension** & Class/Mosaic & MPFD & Average patch shape complexity \\
\hline \multicolumn{4}{|l|}{ Nearest neighbour } \\
\hline $\begin{array}{l}\text { Mean nearest neighbour } \\
\text { distance }(\mathrm{m})^{* *}\end{array}$ & Class/Mosaic & MNN & $\begin{array}{l}\text { Average edge-to-edge distance between patches of } \\
\text { the same class }\end{array}$ \\
\hline Mean proximity index ${ }^{* *}$ & Class/Mosaic & MPI & $\begin{array}{l}\text { Average proximity of patches to similar patches } \\
\text { within a user-specified distance }\end{array}$ \\
\hline \multicolumn{4}{|l|}{ Diversity } \\
\hline Patch richness* & Mosaic & PR & Number of patch types composing the mosaic \\
\hline Shannon's evenness index* & Mosaic & SHEI & The distribution of area among all patches \\
\hline \multicolumn{4}{|l|}{ Contagion and interspersion } \\
\hline Contagion $(\%)^{* *}$ & Mosaic & CONTAG & Probability measure of patch dispersion \\
\hline $\begin{array}{l}\text { Interspersion and juxtaposition } \\
\text { index }^{* *}\end{array}$ & Class/Mosaic & IJI & $\begin{array}{l}\text { Measure of the extent to which patch types are } \\
\text { interspersed }\end{array}$ \\
\hline
\end{tabular}

Selecting a spatial extent for landscape analysis: It was assumed that the scale at which metrics best predicted the variation of nekton density was likely to be the scale at which landscape structure had the strongest influence on target species and assemblages. In order to select the most influential spatial extent, the data structure was first simplified by reducing the large number of metrics to a relatively small number of factors using principal component analysis (PCA) (McGarigal \& McComb 1995). Linear regression (STATISTICA, StatSoft, 1995) was used to measure the relationship between each principal component and the animal attributes at each spatial extent (100 and $300 \mathrm{~m}$ radii). Correlation analysis was used to identify statistically significant $(\mathrm{p}<0.05$ ) associations between the animal attributes and substratum variables (withinpatch and landscape structure) at the most influential spatial extent. Redundancy for landscape metrics was assessed by the strength of association, and, where strong co-linearity $(\mathrm{r}=>0.9)$ was identified between 2 metrics, the most ecologically interpretable metric was retained. Non-significant $(p>0.05)$ variables were excluded from subsequent statistical analyses.

Cluster and ordination of landscape structure: To further explore and visualise patterns in the linkages between animal attributes and landscape structure, the large array of landscape metrics were grouped into landscape structural types and then aligned with the biological response variables using a sequence of cluster analysis, ordination and multiple-linear regression techniques within PATN statistical software (Belbin 1995). This followed the approach of McAlpine et al. (1999) and McAlpine \& Eyre (2002) and is used as a purely exploratory way of identifying key landscape variables for use in path analysis. First, samples were fused into groups with similar structural attributes using agglomerative hierarchical cluster analysis (flexible-unweighted pair group arithmetic averaging) (Bel- 
bin et al. 1992, Belbin \& McDonald 1993). Summary statistics on individual landscape metrics were generated for each group to describe landscape structural types (LSTs). Next, semi-strong hybrid multidimensional scaling (Belbin 1991) based on the Bray-Curtis coefficient of dissimilarity (Bray \& Curtis 1957) was applied to simplify the data structure and produce a 2-dimensional plot representing landscape structure. Principal axis correlation (PCC) was applied to determine how well the individual metrics fitted the ordination of landscape structure. This is essentially a multiple-linear regression analysis that gives the direction of best fit and the correlation of each metric with the ordination (Belbin 1995). Metrics with high correlation (>0.8) with the landscape structural types were plotted on the 2-dimensional plot. Finally, the data for animal density and number of species were plotted on the ordination to examine their alignment with the landscape structural types and the individual landscape metrics.

Path analysis: Path analysis (Wright 1921, Mitchell 1992, Wootton 1994, Shipley 1997, 2000), a straightforward extension of multiple regression, was used to decompose correlations into their causal (direct) and non-causal (indirect) components and to allow simple correlations among a set of variables to be partitioned according to a particular working model (path model) about their causal relationships. Each path coefficient was scaled to range from -1 to +1 , as with standardised regression coefficients. The SEPATH structural equation modelling module (Steiger 1995) in STATISTICA v9 was used to test models by comparing the estimated correlation matrix with the observed correlation matrix. Competing models were tested using a range of goodness-of-fit statistics and a final model selected on the basis of overall performance of the measures of model fit. Hypotheses $\left(H^{1}, H^{2}, H^{3}\right.$ and $\left.H^{4}\right)$ were tested for: (a) assemblage density, (b) number of species and (c) density of individual species, using the presence and absence of statistically significant path coefficients. The hypotheses were:

$H^{1}$ : The structure of the whole landscape mosaic is significant.

$H^{2}$ : The structure of individual habitat types is significant.

$H^{3}$ : The area of individual habitat types is more influential than spatial configuration.

$H^{4}$ : The within-patch structure is significant.

\section{RESULTS}

\section{Linkages between nekton and landscape structure}

Summation of the coefficients of determination (r) for the relationships between nekton attributes and land- scape metrics for each spatial extent (100 and $300 \mathrm{~m}$ ) showed that the total value for $300 \mathrm{~m}$ was $31 \%$ higher than for $100 \mathrm{~m}$. The difference was statistically significant (ANOVA, $F=3.84, \mathrm{p}<0.05$ ), and all subsequent analyses used data calculated at the $300 \mathrm{~m}$ spatial extent.

The agglomerative hierarchical cluster analysis (flexible-UPGMA) fused samples of landscape mosaic structure into 10 groupings of LSTs; 3 of the LSTs were composed of $<5$ samples and were merged with the next most similar group, resulting in 7 classes, as shown in Figs 3 \& 4 .

\section{Assemblage level}

For assemblages using tidal flats, highest density and number of species were spatially associated with the most diverse and heterogeneous landscape structural types (LST1, 3 and 4) (Fig. 3a \& b). These groups contained landscape mosaics with high vegetation cover and were characterised by high metric values for total edge, interspersion and juxtaposition of patches, patch richness and Shannon diversity index. Overall, the highest assemblage densities and number of species were concentrated within and immediately surrounding LST3, which was dominated (90\%) by continuous seagrass habitats, with $10 \%$ patchy vegetation. Lowest densities were associated with LST5, 6 and 7, which were composed of largely unvegetated mosaics and characterised by high values of the largest patch index and mean patch size and low values of the Shannon diversity index, number of patches and total edge. In contrast, no clear pattern emerged for the density of assemblages using mangroves at high tide (data not shown). However, number of species was markedly higher in mangroves within vegetated landscape mosaics. These were characterised by high habitat diversity and heterogeneity and a high abundance of long-leaved seagrasses (dominated by Zostera capricorni) in the adjacent intertidal flats.

\section{Species level}

Spatial patterns in species density indicated a preference for continuously vegetated landscapes (LST1 and 3 ) for the most abundant fish species, Pelates sexlineatus (Fig. 4a) and the most abundant prawn species, Metapenaeus bennettae (Fig. 4b). However, M. bennettae also showed relatively high densities in patchy landscapes (LST4) and in the largely unvegetated landscapes (LST5, 6 and 7). The other abundant fish species (Centropogen australis; Arenigobius frenatus; Mugilogobius stigmaticus and Acanthropagrus aus- 

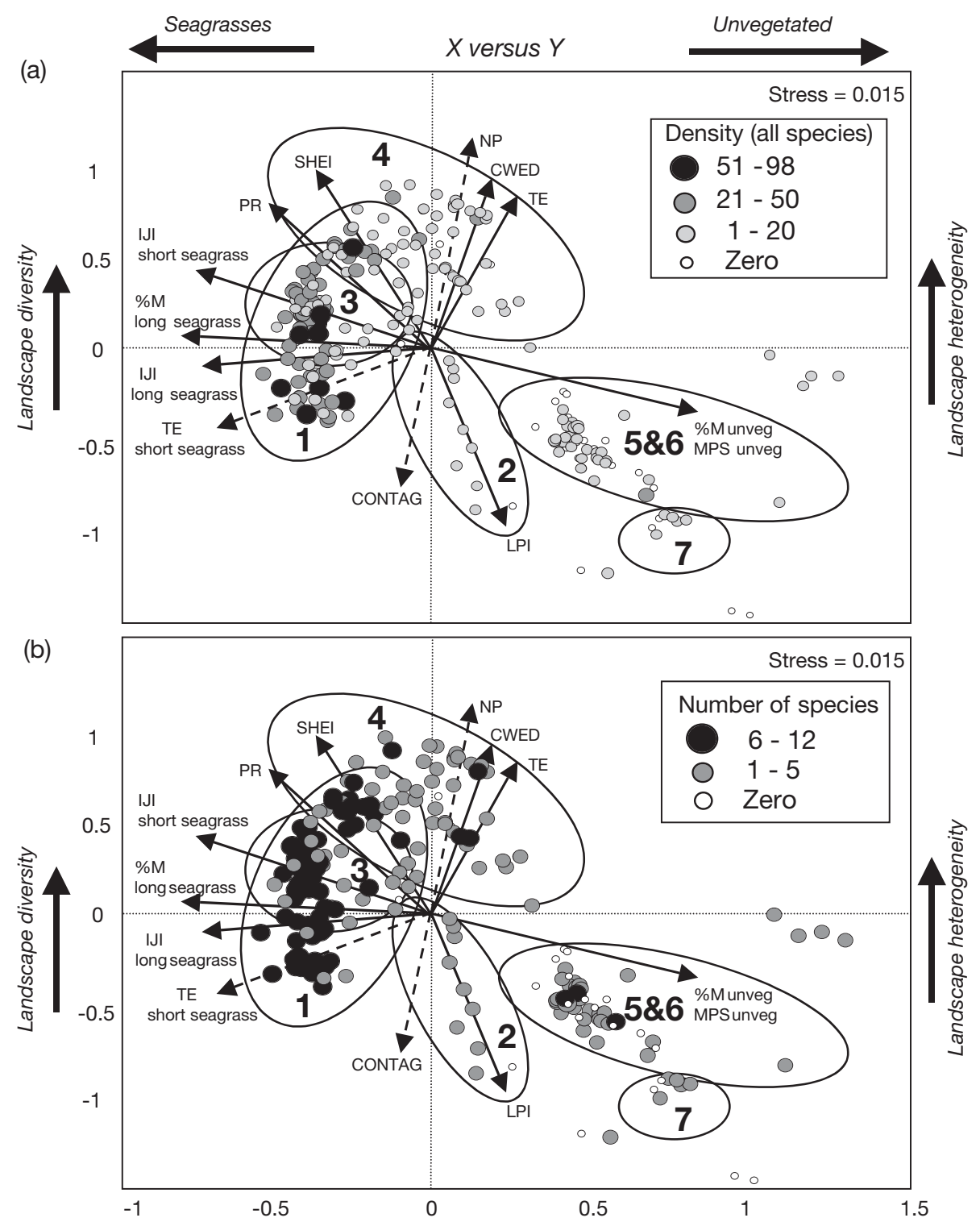

Fig. 3. Multidimensional scaling ordination of: (a) assemblage density and (b) number of species. The 7 groups from the cluster analysis (landscape structural types) are encircled. Vectors represent the direction and strength of each metric in the ordination space (solid arrows: principal axis correlation of $\geq 0.9$ i broken arrows: principal axis correlation of $<0.9$; NP: number of patches; CWED: contrast weighted edge density; TE: total edge; \%M: percent of mosaic; MPS: mean patch size; CONTAG: contagion; IJI: interspersion and juxtaposition index; PR: patch richness; SHEI: Shannon's evenness; LPI largest patch index); unveg: unvegetated

tralis) (data not shown) also revealed highest densities in LST1 and 3, except Sillago spp., which revealed a preference for landscapes with mangroves, adjacent patches of short-leaved seagrass habitats and large patches of unvegetated substratum. These patchily vegetated landscapes were characterised by high metric values for total edge, contrast weighted edge density, mean patch fractal dimension and mean patch size for unvegetated substratum.

\section{Path models of potential causality}

Sets of statistically significant correlates selected for path analysis are listed in Tables 3 \& 4 . Water variables had little influence on density (or number of species) at either the assemblage or species level. Water depth, however, was significantly correlated with number of fish species within mangroves $(r=0.18, p<0.05)$ and the density of Arenigobius frenatus ( $\mathrm{r}=0.24, \mathrm{p}<0.05)$, but was not significant in the final path models. All levels of benthic structure (landscape, habitat type and within-patch) contributed to the final path models for assemblage density and number of species (Figs. 5 \& $6)$. In contrast, for individual species, only variables for habitat type and within-patch structure contributed to final path models (Fig. 7, see also Fig. 9).

Path models for nekton using mangroves at high tide explained significantly less (mean $22.6 \pm 4.7 \% \mathrm{SE}$ ) of the total variation (at both the assemblage and species level) than did models for nekton using adjacent tidal flats (mean $59.6 \pm 4.3 \% \mathrm{SE}$ ) (ANOVA $F=32.9$, p < 

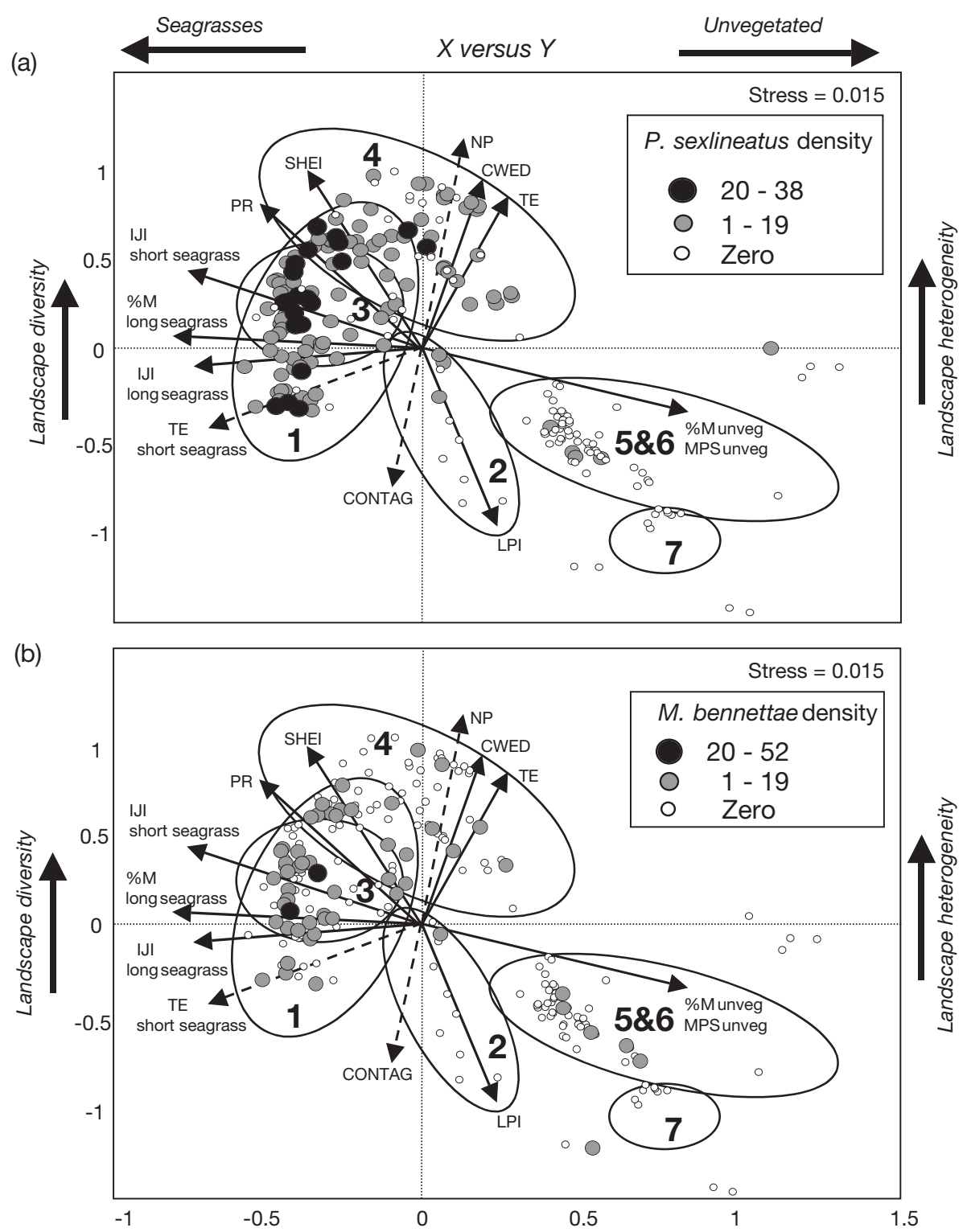

Fig. 4. Multidimensional scaling ordination of: (a) eastern trumpeter Pelates sexlineatus and (b) bay prawn Metapenaeus bennettae. The 7 groups from the cluster analysis (landscape structural types) are encircled. Vectors represent the direction and strength of each metric in the ordination space (solid arrows: principal axis correlation of $\geq 0.9$; broken arrows: principal axis correlation of $<0.9$; NP: number of patches; CWED: contrast weighted edge density; TE: total edge; \%M: percent of mosaic; MPS: mean patch size; CONTAG: contagion; IJI: interspersion and juxtaposition index; PR: patch richness; SHEI: Shannon's evenness; LPI largest patch index); unveg: unvegetated
0.001). Although some variables appeared in more than one path model, each model was composed of a different set of explanatory variables. All final models offered a good fit as indicated by a range of goodnessof-fit statistics (Table 5). Results of hypothesis testing are summarised in Tables $6 \& 7$.

\section{Hypothesis 1. Influence of landscape mosaic composition and configuration}

For assemblages using mangroves at high tide, landscape spatial configuration (represented by mean nearest neighbour distance) was significant for both density (path coefficient $[\mathrm{pc}]=0.28, t=2.88, \mathrm{p}<0.01$ ) and number of species ( $\mathrm{pc}=0.28, t=2.78, \mathrm{p}<0.01$ ) (Fig. 5). For assemblages using tidal flats (Fig. 6), patch richness and the landscape interspersion and juxtaposition index (measures of landscape mosaic structure) improved the overall fit of the model, but were not statistically significant. These variables were more important for number of species than for density. Overall, the spatial configuration and habitat diversity of the whole landscape mosaic explained less variation in assemblage attributes than did the percentage of the landscape occupied by individual habitats or withinpatch structure. At the species level, patch richness was an influential variable for density of Pelates sexlineatus (eastern trumpeter), although it did not explain a significant proportion of the variation (Fig. 7a). For the other species (Fig. 7b to d), explanatory variables at the landscape mosaic level did not contribute to the final path models. 
Table 3. Statistically significant $(\mathrm{p}<0.01)$ explanatory variables for assemblages and species using mangroves at high tide. Variables with negative associations are also shown (negative values). Correlation coefficients (r) are shown in parentheses. Explanations of abbreviated landscape metrics are provided in Table 2

\begin{tabular}{|c|c|c|c|}
\hline \multirow[t]{2}{*}{ Response variable } & \multicolumn{3}{|c|}{ Significant explanatory variables at multiple spatial scales } \\
\hline & Within-habitat & Habitat type & Whole mosaic \\
\hline Assemblage density & $\% \operatorname{mud}(0.17)$ & $\begin{array}{l}\text { MPFD mangrove }(-0.12) \\
\text { MNN mangrove }(0.13)\end{array}$ & MNN $(0.21)$ \\
\hline Number of species & $\begin{array}{l}\text { Water depth }(0.18) \\
\% \text { mud }(0.21)\end{array}$ & $\begin{array}{c}\text { \% unvegetated }(-0.26) \\
\text { CA mangrove }(0.17) \\
\% \text { long-leaved seagrasses }(0.34)\end{array}$ & $\begin{array}{l}\text { MNN }(0.24) \\
\text { PR }(0.26) \\
\text { IJI }(0.27)\end{array}$ \\
\hline Sillago spp. density & None & $\begin{array}{c}\text { CA unvegetated sand }(0.36) \\
\% \text { long-leaved seagrasses }(-0.33) \\
\text { CA mangrove }(0.19)\end{array}$ & $\begin{array}{l}\text { SHEI }(-0.24) \\
\text { LPI }(0.21)\end{array}$ \\
\hline Acanthropagrus australis density & $\begin{array}{l}\text { Shoot and root height }(0.24) \\
\% \text { mud }(0.29)\end{array}$ & $\begin{array}{l}\text { MPS long-leaved seagrasses }(0.28) \\
\text { IJI mangrove }(0.30) \\
\% \text { long-leaved seagrasses }(0.27)\end{array}$ & $\begin{array}{l}\text { PR }(0.18) \\
\text { IJI }(0.19)\end{array}$ \\
\hline Arenigobius frenatus density & $\begin{array}{l}\text { Water depth }(0.24) \\
\quad \% \text { mud }(0.36)\end{array}$ & $\begin{array}{l}\text { \% unvegetated }(-0.37) \\
\text { MPS long-leaved seagrasses }(0.36) \\
\text { IJI long-leaved seagrasses }(0.33)\end{array}$ & $\mathrm{PR}(0.23)$ \\
\hline
\end{tabular}

Table 4. Statistically significant $(\mathrm{p}<0.01)$ explanatory variables for assemblages and species using tidal flats at high tide. Variables with negative are also shown (negative values). Correlation coefficients ( $\mathrm{r}$ ) are shown in parentheses. Explanations of abbreviated landscape metrics are provided in Table 2

\begin{tabular}{|c|c|c|c|}
\hline \multirow{2}{*}{ Response variable } & \multicolumn{3}{|c|}{ Significant explanatory variables at multiple spatial scales } \\
\hline & Within-habitat & Habitat type & Whole mosaic \\
\hline Assemblage density & $\begin{array}{l}\text { Shoot density }(-0.32) \\
\% \text { cover }(0.59) \\
\text { Leaf length }(0.44) \\
\% \text { mud }(0.50) \\
\% \text { sand }(-0.74) \\
\% \text { organics }(0.55)\end{array}$ & $\begin{array}{c}\% \text { long-leaved seagrasses }(0.56) \\
\% \text { all seagrasses }(0.73) \\
\text { IJI short-leaved seagrasses }(0.42) \\
\text { IJI long-leaved seagrasses }(0.58) \\
\% \text { unvegetated }(-0.77)\end{array}$ & $\begin{array}{l}\text { SHDI }(0.51) \\
\text { PR }(0.49) \\
\text { SHEI }(0.36) \\
\text { LPI }(-0.53)\end{array}$ \\
\hline Number of species & $\begin{array}{c}\text { Shoot density }(-0.30) \\
\% \text { cover }(0.40) \\
\text { Leaf length }(0.29) \\
\text { Seagrass species }(0.28) \\
\% \text { mud }(0.52) \\
\% \text { sand }(-0.76) \\
\% \text { organics }(0.57)\end{array}$ & $\begin{array}{c}\% \text { long-leaved seagrasses }(0.57) \\
\% \text { all seagrasses }(0.78) \\
\text { IJI short-leaved seagrasses }(0.41) \\
\text { IJI long-leaved seagrasses }(0.56) \\
\% \text { unvegetated }(-0.74)\end{array}$ & $\begin{array}{l}\text { SHDI }(0.61) \\
\text { PR }(0.58) \\
\text { SHEI }(0.62) \\
\text { CWED }(0.31) \\
\text { IJI }(0.56) \\
\text { LPI }(-0.51)\end{array}$ \\
\hline Pelates sexlineatus density & $\begin{array}{l}\text { Shoot density }(-0.55) \\
\% \text { cover }(0.46) \\
\text { Leaf length }(0.39) \\
\% \text { mud }(0.33) \\
\% \text { organics }(0.44) \\
\% \text { sand }(-0.68)\end{array}$ & $\begin{array}{c}\text { TCA long-leaved seagrasses }(0.72) \\
\% \text { long-leaved seagrasses }(0.61) \\
\% \text { all seagrasses }(0.50) \\
\text { IJI short-leaved seagrasses }(0.33) \\
\text { IJI long-leaved seagrasses }(0.43) \\
\% \text { unvegetated }(-0.67)\end{array}$ & $\begin{array}{l}\text { SHDI }(0.62) \\
\text { PR }(0.67) \\
\text { LPI }(-0.46)\end{array}$ \\
\hline Centropogen australis density & $\begin{array}{l}\text { Shoot density }(-0.57) \\
\text { \% cover }(0.62) \\
\text { Leaf length }(0.46) \\
\% \text { mud }(0.44) \\
\% \text { organics }(0.41) \\
\text { \% sand }(-0.55) \\
\text { Grain size }(-0.37)\end{array}$ & $\begin{array}{c}\% \text { long-leaved seagrasses }(0.51) \\
\% \text { all seagrasses }(0.51) \\
\text { TCA long-leaved seagrasses }(0.55) \\
\text { IJI short-leaved seagrasses }(0.25) \\
\text { IJI long-leaved seagrasses }(0.38) \\
\% \text { unvegetated }(-0.53)\end{array}$ & $\begin{array}{l}\text { SHDI }(0.48) \\
\text { PR }(0.41) \\
\text { LPI }(-0.48)\end{array}$ \\
\hline Metapenaeus bennettae density & $\begin{array}{l}\% \text { mud }(0.32) \\
\% \text { organics }(0.39) \\
\% \text { sand }(-0.51)\end{array}$ & $\begin{array}{c}\% \text { short-leaved seagrasses }(0.33) \\
\% \text { long-leaved seagrasses }(0.16) \\
\% \text { all seagrasses }(0.48) \\
\% \text { unvegetated }(-0.38)\end{array}$ & PR $(0.28)$ \\
\hline
\end{tabular}


Table 5. Summary of measures of overall fit of the path models influencing animal attributes at the assemblage and species level for mangroves and adjacent tidal flats. A good fit to the model required that the chi-squared statistic is small and the associated probability $(p)$ is $>0.1$. The goodness-of-fit index (GFI) (McDonald \& Marsh 1990) and the adjusted goodness-of-fit index (AGFI) (Tanaka \& Huba 1989) with values $>0.9$ indicate a good fit. The model Akaike information criterion (AIC) (Akaike 1973) with the smallest value indicates the statistically preferred model for the data. Indices based on the residuals also are an indication of fit, and the root mean square error of approximation (RMSEA) measured the error of the model, with values $<0.1$ indicating a good fit

\begin{tabular}{|lccccc|}
\hline & Chi-squared (p) & RMSEA & GFI & AGFI & AIC \\
\hline Mangrove & & & & & \\
Assemblage & & & & & \\
$\quad$ Density & $0.80(0.38)$ & 0 & 0.99 & 0.94 & 0.50 \\
$\quad$ Number of species & $1.91(0.98)$ & 0 & 0.99 & 0.97 & 0.69 \\
Species & & & & & \\
$\quad$ Sillago spp. & $5.53(0.24)$ & 0.06 & 0.98 & 0.96 & 0.65 \\
$\quad$ Acanthropagrus australis & $2.58(0.99)$ & 0 & 0.99 & 0.97 & 1.27 \\
$\quad$ Mugilogobius stigmaticus & $10.2(0.18)$ & 0.06 & 0.98 & 0.87 & 0.79 \\
& & & & & \\
Adjacent tidal flat & & & & & \\
Assemblage & & & & & \\
$\quad$ Density & $1.01(0.32)$ & 0.01 & 0.99 & 0.76 & 1.87 \\
$\quad$ Number of species & $3.21(0.20)$ & 0.13 & 1 & 1 & 2.87 \\
Species & & & & & \\
$\quad$ Pelates sexlineatus & $0.18(0.66)$ & 0 & 0.99 & 0.93 & 3.15 \\
$\quad$ Centropogen australis & $5.73(0.22)$ & 0.11 & 0.96 & 0.62 & 2.31 \\
$\quad$ Arenigobius frenatus & $6.76(0.23)$ & 0.13 & 0.96 & 0.56 & 2.33 \\
$\quad$ Metapenaeus bennettae & $8.44(0.20)$ & 0.11 & 1 & 1 & 4.68 \\
$\quad$ Penaeus plebejus & $6.53(0.36)$ & 0.05 & 1 & 1 & 3.96 \\
\hline
\end{tabular}

Hypotheses 2 and 3. Influence of spatial configuration and area of individual habitat classes

For assemblages using tidal flats, path analysis indicated that the proportion of all seagrass habitats was statistically significant for density ( $\mathrm{pc}=0.59, t=2.44$, p < 0.01) (Fig. 6a), and the percentage of long-leaved seagrass habitats was statistically significant for number of species ( $\mathrm{pc}=0.33, t=1.85, \mathrm{p}<0.01$ ) (Fig. 6b).
Furthermore, linear regression showed a strong positive relationship between the proportion of all seagrass habitats in the landscape and assemblage density and number of species $\left(\mathrm{r}^{2}=0.40\right.$ and 0.48, p < 0.001) (Fig. 8). Significant positive relationships also were found between the proportion of long-leaved seagrasses and the assemblage density and number of species $\left(\mathrm{r}^{2}=0.34\right.$ and 0.30 respectively, $\mathrm{p}<0.001)$. Overall, the strength and statistical significance of path coefficients indicated that the area of suitable habitat type was significantly more influential than measures of spatial configuration.

For assemblages using mangroves, mean nearest neighbour distance of mangroves (landscape configuration) was significant $(\mathrm{pc}=0.59, t=2.19, \mathrm{p}<$ 0.01 ) and explained the highest proportion of variation in the model for assemblage density (Fig. 5a). The proportion of mangroves in the landscape was not a significant variable. Mean patch fractal dimension of mangroves was a negative explanatory variable, but was not statistically significant. For the number of species using mangroves, the proportion of long-leaved seagrass in the landscape had a positive influence with the percentage of unvegetated sand having a negative influence (Fig. 5b). Furthermore, mangroves with adjacent seagrasses (>70\% cover) supported significantly higher numbers of fish species than did mangroves with adjacent patchy seagrasses $(<30 \%$ cover) (ANOVA $F=16.2$, p <0.001). However, only core area of mangroves was significant in the final path model ( $\mathrm{pc}=0.43, t=1.71, \mathrm{p}<0.01)$.

Table 6. Interpretation of the results of hypothesis testing for linkages between substratum structure and nekton assemblage density and number of species. Alternative hypotheses were accepted or rejected based on the presence or absence of statistically significant $(\mathrm{p}<0.05)$ path coefficients

\begin{tabular}{|ll}
\hline Hypothesis & Key finding \\
\hline$H^{1}:$ Landscape mosaic is significant & $\begin{array}{l}\text { Whole mosaic structure influenced assemblage density and number of species } \\
\text { using mangroves at high tide, but not assemblages using seagrasses }\end{array}$ \\
$H^{2}$ : Structure of habitat type is significant & $\begin{array}{l}\text { Structure of individual habitat type influenced assemblage density and } \\
\text { number of species using seagrasses and mangroves }\end{array}$ \\
$\begin{array}{ll}H^{3}: \text { Area of habitat type more significant } \\
\text { than spatial configuration }\end{array}$ & $\begin{array}{l}\text { Area of individual habitat type was more influential than configuration for } \\
\text { number of species using mangroves and seagrasses and for assemblage } \\
\text { density using seagrasses, but not assemblage density within mangroves }\end{array}$ \\
$H^{4}$ : Within-patch structure is significant & $\begin{array}{l}\text { Within-patch structure influenced assemblages (density and number of } \\
\text { species) using mangroves at high tide and number of species using sea- } \\
\text { grasses, but not density using seagrasses }\end{array}$ \\
\hline
\end{tabular}


Table 7. Interpretation of the results of hypothesis testing for linkages between substratum structure and density of individual species. Alternative hypotheses were accepted or rejected based on the presence or absence of statistically significant $(\mathrm{p}<0.05)$ path coefficients

\begin{tabular}{|c|c|}
\hline Hypothesis & Key finding \\
\hline$H^{1}$ : Landscape mosaic is significant & Whole mosaic structure did not influence density of individual species \\
\hline$H^{2}$ : Structure of habitat type is significant & $\begin{array}{l}\text { Structure of individual habitat type influenced abundant species (Pelates } \\
\text { sexlineatus, Centropogen australis, Arenigobius frenatus, Metapenaeus } \\
\text { bennettae) using seagrasses at high tide and gobies (Mugilogobius stigmati- } \\
\text { cus) using mangroves, but not transient fish species (Sillago spp. and Acan- } \\
\text { thropagrus australis) using mangroves at high tide }\end{array}$ \\
\hline $\begin{array}{l}H^{3}: \text { Area of habitat type more significant } \\
\text { than spatial configuration }\end{array}$ & $\begin{array}{l}\text { Area of individual habitat type was more influential than spatial configuration } \\
\text { for all abundant species }(P \text {. sexlineatus, } C \text {. australis, } A \text {. frenatus, } M \text {. } \\
\text { bennettae) using seagrasses at high tide, but not species using mangroves at } \\
\text { high tide }\end{array}$ \\
\hline$H^{4}$ : Within-patch structure is significant & $\begin{array}{l}\text { Within-patch structure influenced penaeid prawns ( } M \text {. bennettae) and } 2 \\
\text { species (A. australis and } M \text {. stigmaticus) using mangroves at high tide }\end{array}$ \\
\hline
\end{tabular}
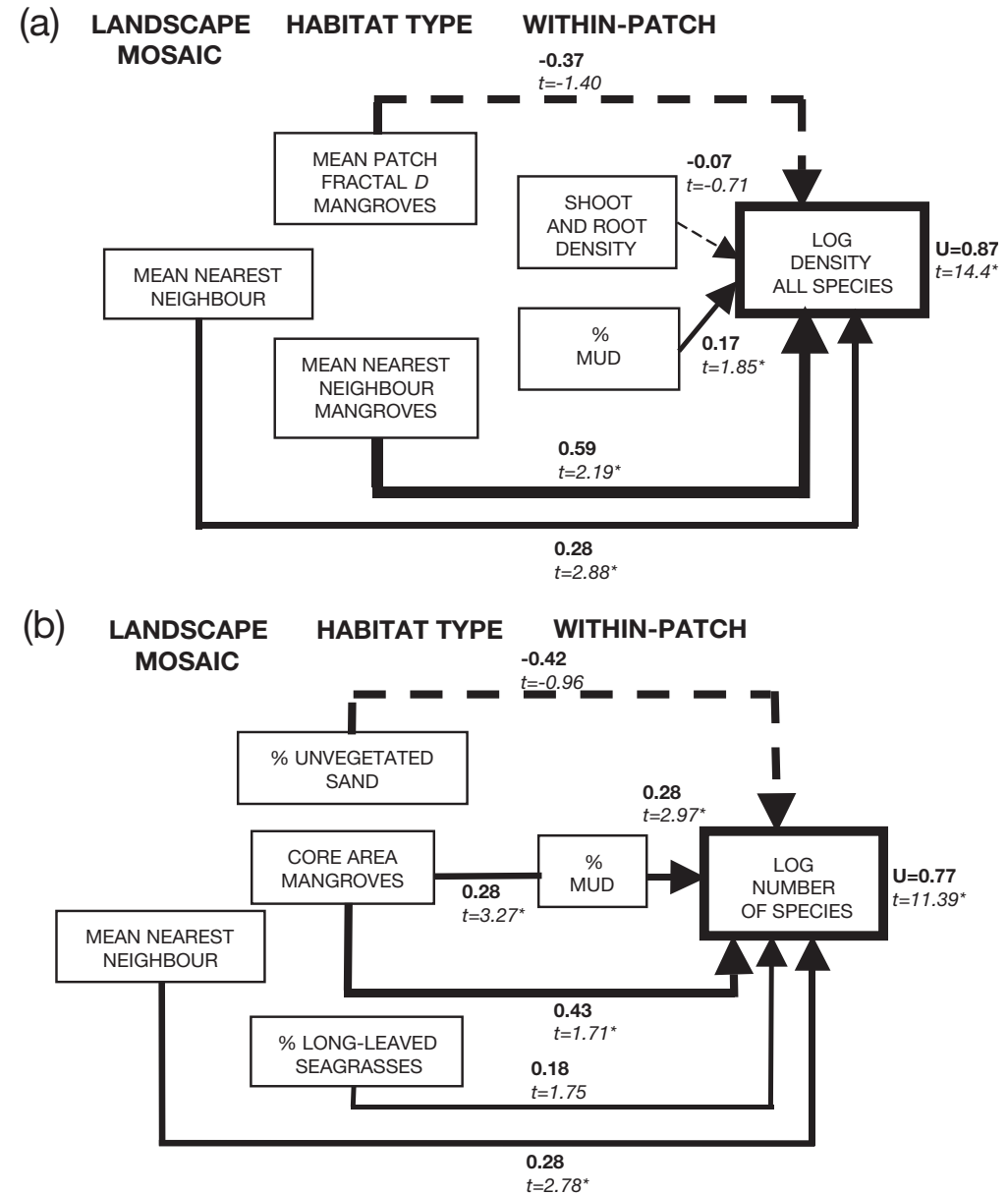

Fig. 5. Path diagram estimating the relative importance of direct and indirect effects of environmental variables on: (a) assemblage density and (b) number of species within mangroves at northern Deception Bay. Arrows represent directed relationships. Width of each line is proportional to the value of the parameter estimate (path coefficient). Asterisk indicates a statistically significant $(\mathrm{p}<0.05)$ path coefficient. Broken lines indicate negative paths. U: unexplained variation
For the individual species, the area of long-leaved seagrass habitats was statistically significant for Pelates sexlineatus and explained the highest proportion of variation in the model (Fig. 7a). Interspersion and juxtaposition (configuration) of long-leaved seagrasses made only a very small contribution to the overall explanation for this species. For Centropogen australis (the second most abundant species), the percentage of all seagrass habitats was statistically significant ( $\mathrm{pc}=0.40, t=2.10$, $\mathrm{p}<0.01)$ and contributed most to the final model (Fig. 7c). This preference for vegetated landscapes was explained further by positive coefficients for the metrics that represented the abundance of long-leaved seagrass habitats in the landscape. Landscapes with a large proportion of long-leaved seagrass habitats were preferred by Arenigobius frenatus, with mean patch size of long-leaved seagrasses contributing most to the explanation of variation in density ( $\mathrm{pc}=$ 0.51, $t=1.66, \mathrm{p}<0.01$ ) (Fig. 7b). For the penaeid prawn Metapenaeus bennettae, the percentage of all seagrasses ( $\mathrm{pc}=0.40, t=1.07, \mathrm{p}<0.01$ ) and the percentage of short-leaved seagrass habitats ( $\mathrm{pc}=0.37, t=1.77, \mathrm{p}<0.01)$ had significant positive influences, while the proportion of long-leaved seagrass habitats had a weak negative influence (Fig. 7d). 
(a)

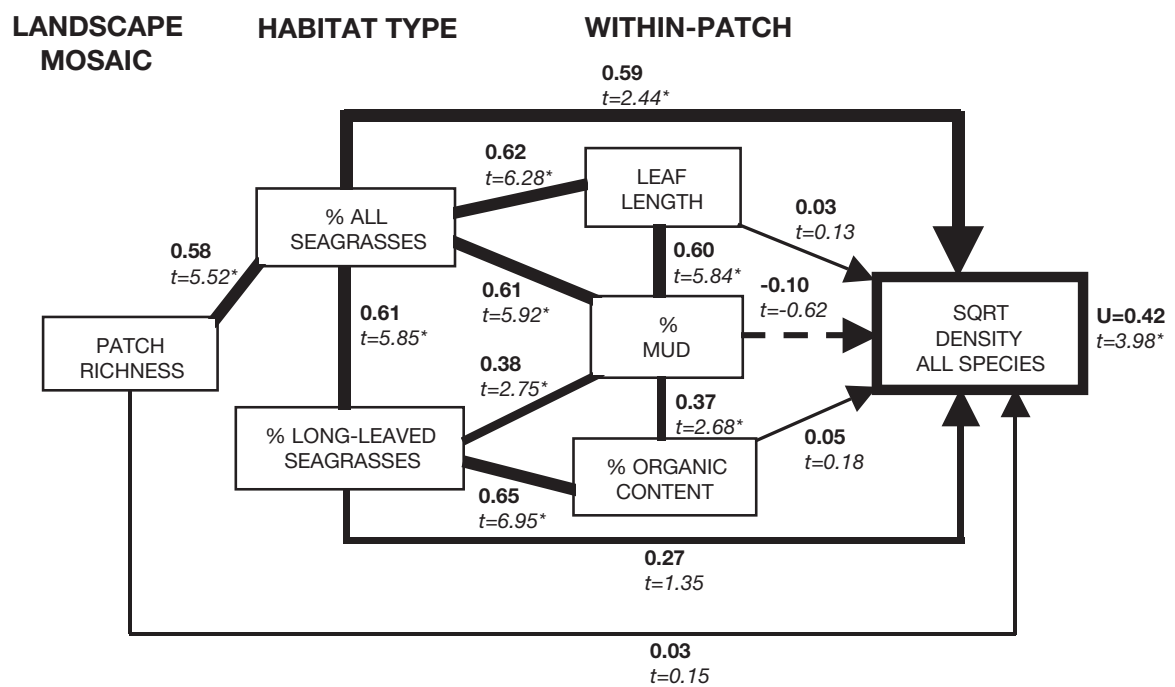

(b)

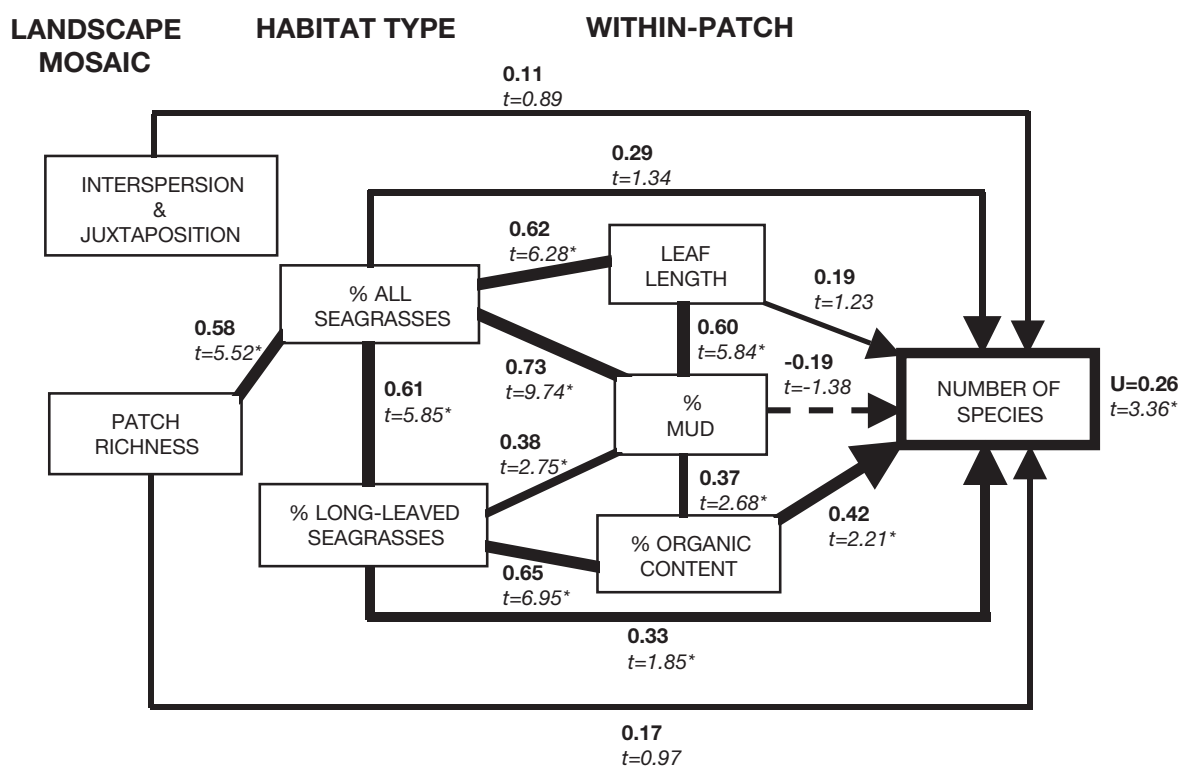

Fig. 6. Path diagram estimating the relative importance of direct and indirect effects of environmental variables on: (a) assemblage density and (b) number of species over tidal flats at northern Deception Bay. Arrows represent directed relationships and wires (no arrowhead) represent undirected relationships. Width of each line is proportional to the value of the parameter estimate (path coefficient). Asterisk indicates a statistically significant $(\mathrm{p}<$ 0.05) path coefficient. Broken lines indicate negative paths. U: unexplained variation
For species using mangroves at high tide, the spatial pattern of both mangroves and adjacent tidal flats contributed to the explanatory models for variation in density across the study area. For Acanthropagrus australis (yellow-finned bream), mean patch size of longleaved seagrasses in the adjacent tidal flats was influential, as was the interspersion and juxtaposition of mangroves, although neither was statistically significant (Fig. 9a). The path model for Sillago spp. (Fig. 9b) was the only model to comprise variables from only a single structural level. Core area of unvegetated sand and contrast-weighted edge density of mangroves were the strongest positive correlates, with the percentage of long-leaved seagrasses having a negative influence. However, none of the variables were statis- tically significant. For Mugilogobius stigmaticus (mangrove goby), mean patch size of long-leaved seagrasses was a significant explanatory variable, with interspersion and juxtaposition of mangroves influential, but not statistically significant (Fig. 9c).

\section{Hypothesis 4. Influence of within-patch structure}

For assemblages using tidal flats, variation in leaf length and the proportion of mud and organic content in surficial sediments all contributed to the final path models for both density and number of species. These variables explained a higher proportion of the variation for number of species than for density (Fig. 6). 
(a)

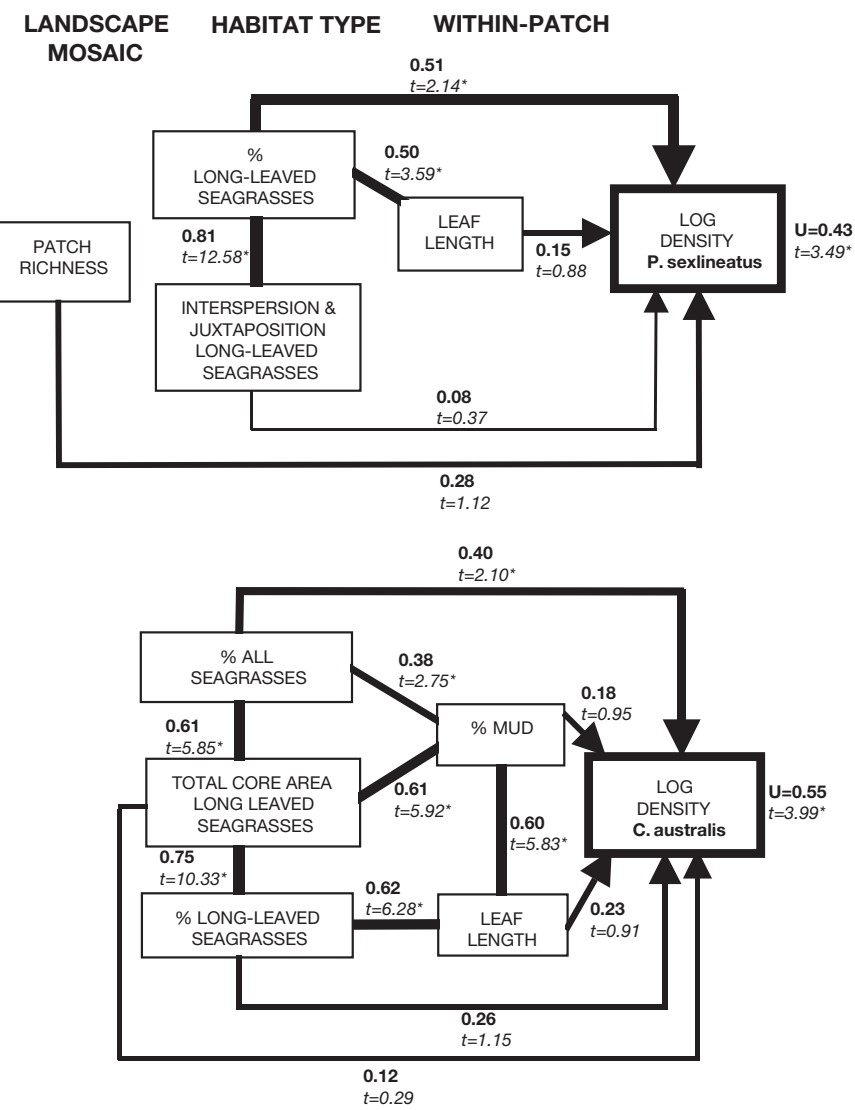

(b)
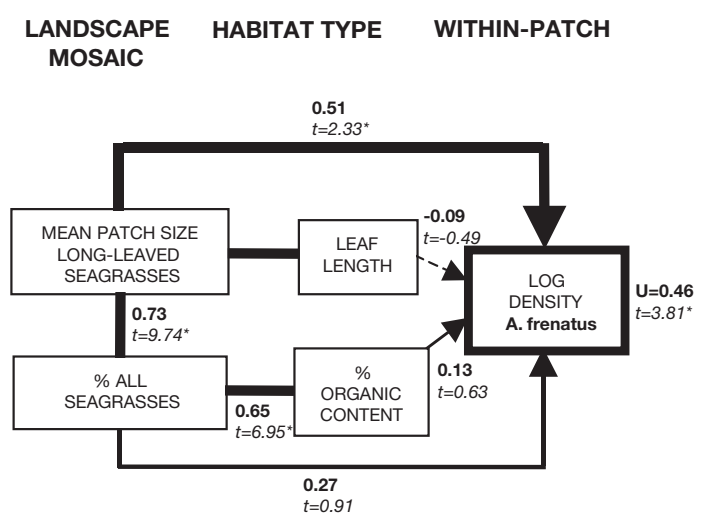

(d)

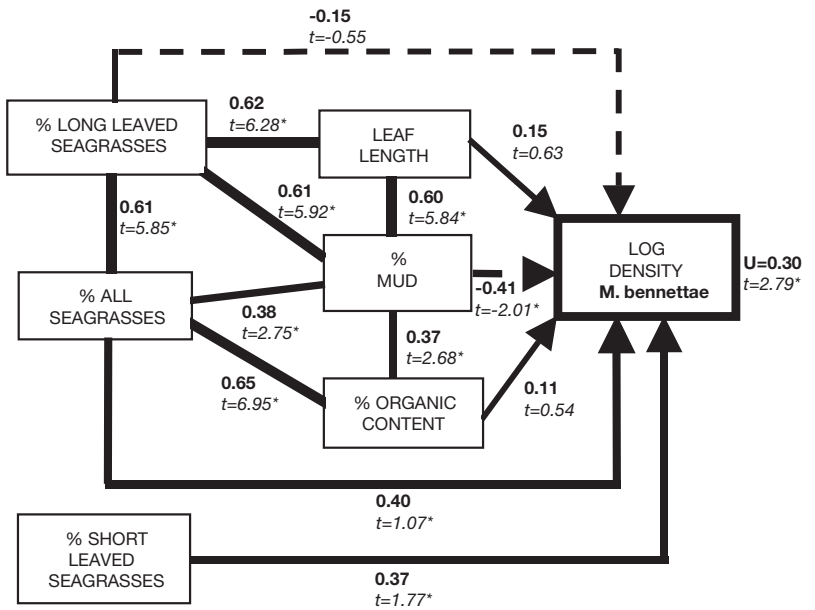

Fig. 7. (a) Eastern trumpeter Pelates sexlineatus, (b) barred fortesque Centropogen australis, (c) half-bridled goby Arenigobius frenatus and (d) bay prawn Metapenaeus bennettae. Path diagrams estimating the relative importance of direct and indirect effects of environmental variables on species density over intertidal flats of northern Deception Bay. Arrows represent directed relationships and wires (no arrowhead) represent undirected relationships. Width of each line is proportional to the value of the parameter estimate (path coefficient). Asterisk indicates a statistically significant $(p<0.05)$ path coefficient. Broken line indicates a negative path. U: unexplained variation

However, only the percentage of organic content was statistically significant ( $\mathrm{pc}=0.42, t=2.21, \mathrm{p}<0.01)$.

For assemblages using mangroves at high tide, the proportion of mud was a significant explanatory variable for both density ( $\mathrm{pc}=0.17, t=1.85, \mathrm{p}<0.01)$ and number of species ( $\mathrm{pc}=0.28, t=2.97, \mathrm{p}<0.01$ ) (Fig. 5). Mangrove shoot and root density was also an influential variable, but not statistically significant.

At the species level, the influence of sediment composition and plant structure varied markedly between species. Within-patch variables were the most influential for Acanthropagrus australis, with the proportion of mud in surficial sediments ( $\mathrm{pc}=0.25, t=2.83, \mathrm{p}<$ 0.01 ) and mangrove shoot and pneumatophore height $(\mathrm{pc}=0.17, t=1.91, \mathrm{p}<0.01)$ statistically significant positive correlates (Fig. 9a). Preference for muddy sediments was also shown for Mugilogobius stigmaticus ( $\mathrm{pc}=0.51, t=7.10, \mathrm{p}<0.01$ ) (Fig. 9c). In contrast, the percentage of mud was a strong negative path coeffi- cient $(\mathrm{pc}=0.41, t=2.01, \mathrm{p}<0.01)$ for the penaeid prawn Metapenaeus bennettae (Fig. 7d). Variation in leaf length was positively correlated with the density of Pelates sexlineatus (Fig. 7a) and Centropogen australis (Fig. 7c) and weakly negatively correlated with Arenigobius frenatus (Fig. 7b), but none of the withinpatch variables were statistically significant. Finally, there were no variables representing within-patch structure for Sillago spp. (Fig. 9b).

\section{DISCUSSION}

The study applied a hierarchical landscape approach to identify the major environmental variables influencing the observed spatial patterns in density and number of species for small-bodied and juvenile fish and prawns in Deception Bay, Queensland, Australia. Results indicate that a range of eco- 
(a)

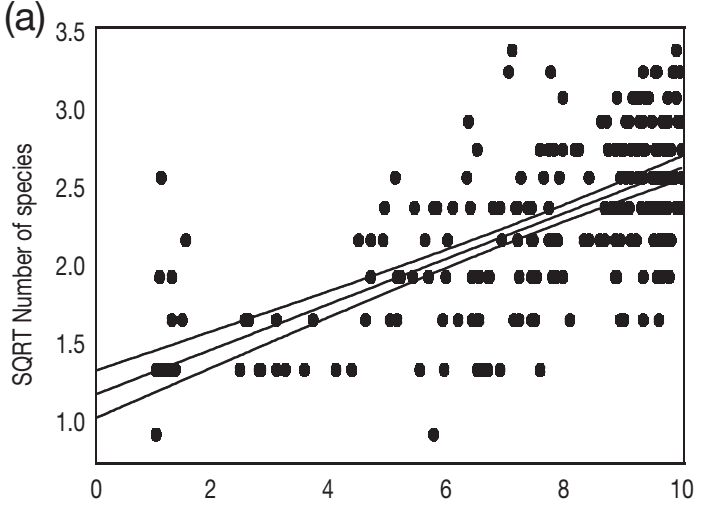

Regression $95 \%$ confid.

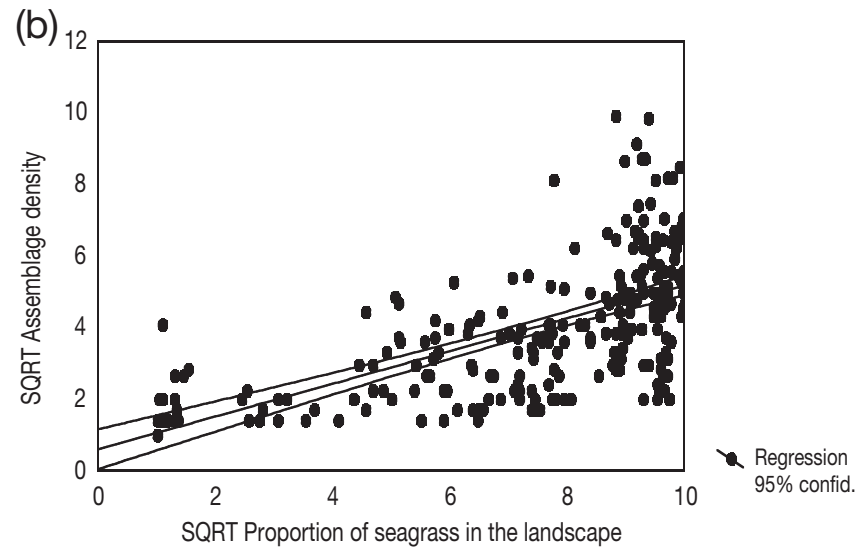

Fig. 8. Linear relationship between the proportion of seagrass in the landscape and (a) number of species $(y=1.24 x+0.15$, $\left.r^{2}=0.48, p<0.001\right)$ and (b) assemblage density $(y=0.58 x+$ $\left.0.46, \mathrm{r}^{2}=0.40, \mathrm{p}<0.001\right)$

logical responses for fish and penaeid prawns exist, some of which appear hierarchical, suggesting that there is no single scale or single measure of substratum structure that alone adequately captures this varied response. The study supports the over-arching axiom in ecology that heterogeneity of physical structure at a range of scales plays a key role in determining the spatial distribution and abundance of animal species (McArthur 1965, Southwood 1977, Kotliar \& Wiens 1990, McCoy \& Bell 1991). More specifically, the composition and spatial arrangement of benthic structure at the level of the landscape unit ( $28 \mathrm{ha}$ ) explained a large and significant proportion of the variation in fish and penaeid prawn density and number of species in Moreton Bay. Overall, fish and prawns using vegetated tidal flats at high tide responded more to landscape composition than spatial configuration, whilst species and assemblages using mangroves at high tide responded more to the spatial configuration of mangroves and adjacent seagrasses, with the areal extent of mangroves influencing number of species but not assemblage density. (a)

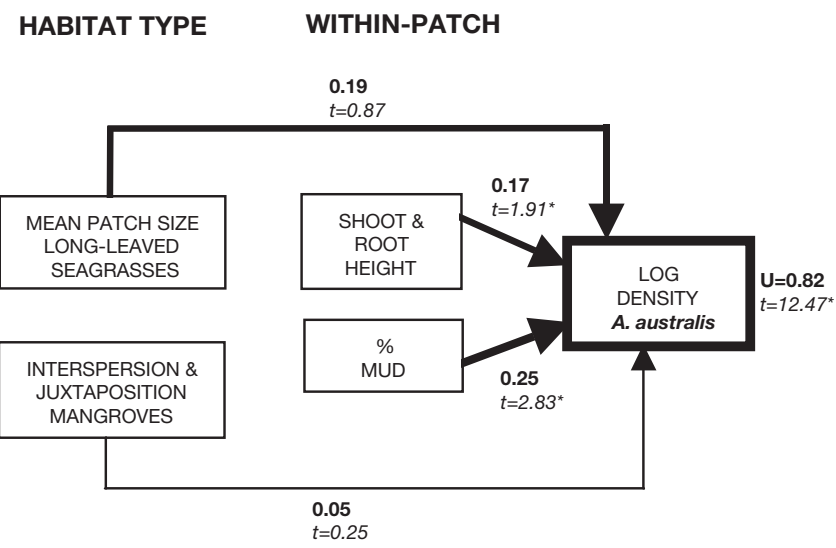

(b)

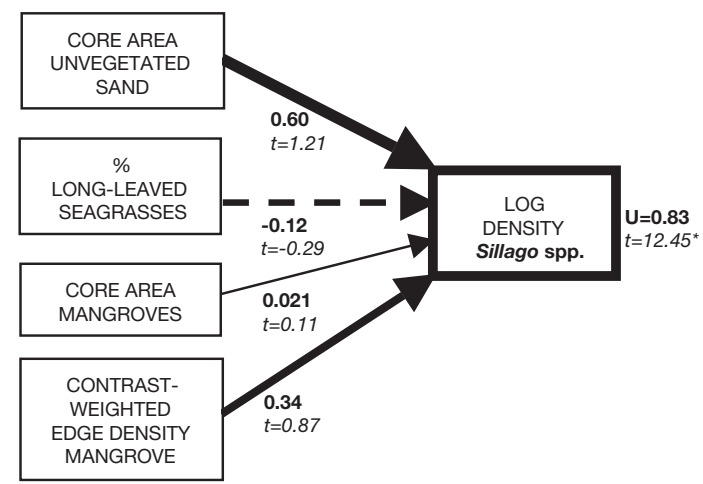

(c)

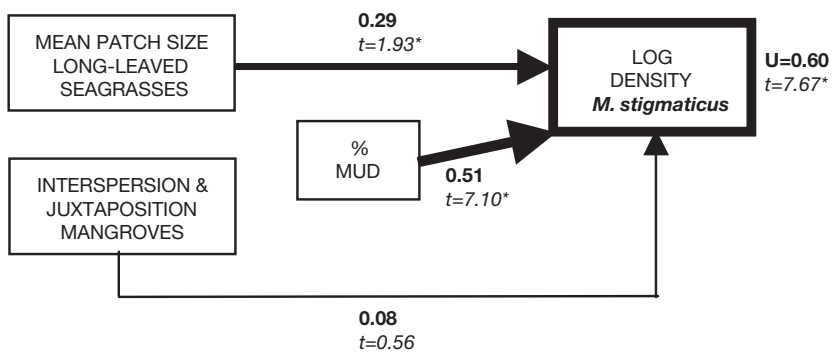

Fig. 9. (a) Whiting Sillago spp., (b) mangrove goby Mugilogobius stigmaticus and (c) yellowfinned bream Acanthropagrus australis. Path diagram estimating the relative importance of direct and indirect effects of environmental variables on the species density within mangroves of northern Deception Bay. Arrows represent directed relationships. Width of each line is proportional to the value of the parameter estimate (path coefficient). Asterisk indicates a statistically significant $(\mathrm{p}<$ 0.05) path coefficient. Broken line indicates a negative path. $\mathrm{U}$ : unexplained variation

\section{Influence of landscape composition}

The area of all seagrass habitats in the landscape, and in particular long-leaved seagrass habitats, were the most influential variables for assemblage density and number of species using tidal flats at high tide. 
This is consistent with the recent assertion by Fahrig $(1997,2003)$ that habitat loss rather than fragmentation is the major driver of population decline. For Pelates sexlineatus, the most abundant seagrass-associated fish species, the proportion of long-leaved seagrasses (>18 cm length) in the landscape provided a better explanation of spatial patterns than did withinpatch measures of leaf length. Furthermore, the results indicate that the density and diversity of fish and prawn species decline linearly with the proportion of the landscape occupied by seagrass habitats (Fig. 7). Such species-area and abundance-area relationships have been described at a range of scales (patch, island, landscape) for both terrestrial and aquatic communities (McArthur \& Wilson 1967, Connor \& McCoy 1979, Andrén 1994, Villard et al. 1999), and add support to an already robust general pattern in ecology. Our results also show that even very low proportions of highly fragmented seagrass habitats support a disproportionately high number of species (albeit low density), until approximately a $20 \%$ seagrass cover threshold, below which, both density and number of species experience a relatively abrupt decline. This critical threshold value is lower than identified by Andrén (1994), who concluded that fragmentation effects become important as the proportion of suitable habitat declines below a critical threshold of $30 \%$ (see also Fahrig 1998, Flather \& Bevers 2002). Other marine studies have found that relatively small patches of seagrasses support unexpectedly high faunal densities and diversity (McNeill \& Fairweather 1993, Bell et al. 2001). It is of value for resource managers to be able to determine critical habitat loss and fragmentation threshold values, in order to prioritise conservation efforts and restore and create connected habitat. That connectivity of seagrass beds is maintained at such low total abundance in the landscape may be explained by the high mobility (active and passive) of organisms in the water column, thereby facilitating transport over broad spatial scales (Bell et al. 2001). However, little is known about the ability of individuals to traverse unvegetated substrata between patches of seagrass, or the extent to which seagrassassociated species are able to utilise resources in the surrounding landscape. Studies using telemetry or experimental micro-landscape studies (e.g. Wiens \& Milne 1989, Crist et al. 1992) may provide useful information on movement behaviour leading to the determination of species-specific (or life-stage specific) functional connectivity and allow investigation into the ability of species to adjust the scale of their movements to the spatial configuration of their habitat. With regard to landscape composition of mangroves, area was not a significant influence on assemblage density, but was a strong predictor for number of species. This may be explained by enhanced refuge function for several specialist species provided by muddy sediments and adjacent long-leaved seagrasses, which characterise landscapes with extensive mangroves in northern Deception Bay.

\section{Influence of landscape spatial configuration}

For assemblages using tidal flats at high tide, landscape spatial configuration was not a significant factor influencing density and number of species, although the interspersion and juxtaposition of patches at the mosaic level was positively linked to number of fish and prawn species. Landscapes with higher interspersion and juxtaposition values have a more evenly interspersed mixture of patch types, and this may increase availability of a wider range of resources than landscapes with more clumping of patch types. In contrast, for assemblages using mangroves at high tide, landscape mosaic configuration and especially the configuration of mangroves were stronger predictors for density and number of species than the amount of mangroves in the landscape. Highest assemblage densities (dominated by Sillago spp.) were found within spatially heterogeneous mangroves. A significant path coefficient for mean nearest neighbour distance inferred a preference for discontinuous mangrove cover or mangroves with large open areas (i.e. more fragmented). Such spatial patterning allows access to the larger bodied and schooling species such as Sillago spp., which appear to exhibit a preference for environments with high edge, high light penetration and plant structure with low shoot density for un-impeded swimming and foraging. For some species, a preference for patchy structure may be a trade-off between minimising the risk of predation, whilst maximising foraging efficiency (Holt et al. 1983, Orth et al. 1984). Terrestrial studies have suggested that some forest bird species (Andrén 1994, McGarigal \& McComb 1995, Trzcinski et al. 1999) and some butterflies (Tscharntke et al. 2002) also may preferentially select highly heterogeneous landscapes.

\section{Influence of landscape mosaic diversity}

Simple correlation analysis indicated that the diversity of habitat types was more influential for assemblages using tidal flats than for individual species, although the relationships were not statistically significant in the final path models. The observation that more diverse landscapes support more diverse animal assemblages has been widespread in ecology (MacArthur 1965, Pearson 1993, McGarigal \& McComb 1995, Jonsen \& Fahrig 
1997). As such, areas with a large number of habitat types are highly desirable as candidates for the selection of protected areas, because they are likely to contain a wide range of species. The use of patch richness as a surrogate for biodiversity has been considered as a potentially useful tool in the selection process of candidate areas for protection (Ward et al. 1999). Care must be taken in comparisons, however, as the interpretation of habitat diversity from mapped data may vary significantly between maps depending on habitat classification and mapping accuracy (Loehle \& Wein 1994, Mumby 2001). High density also may have been maintained through an increase in diversity of different benthic structural classes, representing a potential increase in supplementary resources throughout the home range (Dunning et al. 1992) and a concomitant increase in connectivity where suitable habitat types are adjacent to one another (Jonsen \& Fahrig 1997).

At the species level, patch richness was only important for Pelates sexlineatus, which although a seagrass resident, has been found to have a more flexible dietary spectrum than many other seagrass specialists (Blaber \& Blaber 1980, Warburton \& Blaber 1992), thus allowing the species to benefit from utilising a wide range of seagrass patch types. For instance, dietary studies of $P$. sexlineatus associated with the seagrass Zostera capricorni along the coast of New South Wales, Australia, revealed a diet of 27 different prey items (Sanchez-Jerez et al. 2002).

\section{Influence of adjacent habitat types}

The presence of large patches of long-leaved seagrass habitats in the intertidal flats adjacent to the mangroves appeared to have importance for the gobies, as well as for juvenile Acanthropagrus australis, which used mangroves at high tide. These species utilise multiple habitat types and are typically found using both seagrasses and mangroves. High densities of Arenigobius frenatus were found within mangroves and over adjacent intertidal seagrasses, indicating that A. frenatus is likely to benefit from the close proximity of complementary resources. The linkage between A. australis and seagrasses is more unusual, in that it is a large-bodied tri-phasic species known to have a critical dependence on seagrasses only for the first few weeks after settlement. However, this study also indicates that juveniles and sub-adults have a preference for landscape mosaics with mangroves and adjacent seagrasses in close proximity.

From a landscape perspective, optimal configurations of habitat types may be identified for particular species and assemblages, which function to offer a chain of essential resources supporting species through tidal movements and ontogenetic shifts (Marguillier et al. 1997, Acosta 1999, Nagelkerken et al. 2000, 2001, Cocheret de la Morinière et al. 2003, Gillanders et al. 2003, Mumby et al. 2004). For example, McIvor \& Odum (1988) observed the largest fish populations in areas of a saltmarsh that were opposite streams in which pools offered refuge at low tide. This meant that fish using these areas could feed at high tide in the marsh and retreat to tidal streams at low tide. Micheli \& Peterson (1999) reported that the presence of seagrass habitats connecting reefs to saltmarshes facilitated foraging movements of blue crabs Callinectes sapidus, and Irlandi \& Crawford (1997) found that for an estuarine fish Lagodon rhomboides growth rates and abundance were significantly greater in areas with vegetated intertidal and adjacent vegetated subtidal areas in close proximity than in areas with adjacent unvegetated subtidal. When the close spatial proximity of resources (e.g. settlement substratum, food and refuge) results in higher densities, the ecological process known as landscape complementation can be said to be occurring (sensu Dunning et al. 1992, Schlosser 1995). In Moreton Bay, landscapes that were continuously vegetated from subtidal to upper intertidal zones supported higher densities and numbers of species than landscapes with patchy vegetation. Based on the assumption that high density and diversity of juveniles equals high-quality nursery habitat, we propose that continuously vegetated landscapes have the most important value per unit area for both nursery function and maintenance of biodiversity. In Moreton Bay, these areas should receive special attention in resource management strategies. In addition, future research is needed that focuses on determining the functional connections between adjacent habitat types.

\section{Influence of within-patch structure}

Differences in fine-scale plant structure also were important, and are consistent with previous findings by Bell \& Westoby (1986a, b) and Attrill et al. (2000). In Zostera capricorni beds, Bell \& Westoby (1986a) found highest numbers of species and abundance of fish and crustaceans amongst long and dense seagrasses, and they reported a decrease after experimentally reducing seagrass leaf height. Species preference for seagrasses with the longest leaves (and largest surface area) probably relates to quality of both refuge and food (Orth 1992, Attrill et al. 2000, Hindell et al. 2000). Heck \& Orth (1980) suggested that plants with greater surface area should provide more protection and offer refuge for a wider range of species, including both epibenthic and demersal species, whereas comparatively shorter plants may only provide refuge for 
epibenthic species. The importance of leaf height on potential prey abundance was demonstrated by Connolly \& Butler (1996), who experimentally manipulated seagrass height and demonstrated a reduction of epifauna, which form the major dietary component of small seagrass resident fish species.

In Deception Bay, mangrove plant structure (shoot and pneumatophore height and density) explained little of the variation at the assemblage or species level, except for the density of juvenile Acanthropagrus australis, which was highest within mangroves with the greatest shoot and pneumatophore height. In isolation, this result indicates a preference for increased refuge from larger piscivorous fish, since for many large-bodied fish, high levels of mangrove complexity hinder fish movements (Rönnbäck et al. 1999). Field and laboratory experiments by Laegdsgaard \& Johnson (2001) demonstrated that small juveniles of several species of fish, including Sillago spp., preferentially selected artificial pneumatophores to minimise the risk of predation and to maximise foraging efficiency. However, underwater observations suggested that areas of mangrove with greater vertical structure also experienced lower light penetration due to the close proximity of dense tree canopy. It is possible, therefore, that this apparent preference represented a response to an unmeasured, co-varying factor such as light intensity, which may also contribute to the spatial heterogeneity of habitat quality by influencing both refuge function and foraging efficiency (Laegdsgaard \& Johnson 2001, Cocheret de la Morinière et al. 2004).

The proportion of mud in surficial sediments was the single most influential within-patch variable and represented a key explanatory variable for both density and number of species using mangroves. The goby Mugilogobius stigmaticus showed a strong preference for the muddiest sediments within mangroves, and similar preferences have been investigated for gobies within the Swan Estuary, south-western Australia, where Gill \& Potter (1993) found Arenigobius frenatus selecting the softest sediments to facilitate burrowing. Path models suggest that some seagrass-associated species differentiate between sediment based on the proportions of mud and sand. For example, Centropogen australis and Pelates sexlineatus both showed a preference for patches of long-leaved seagrasses. C. australis, however, was most abundant over the muddiest sediments, and this spatial preference reflects its epibenthic mode of living and high dependency on seagrass-associated invertebrates (particularly penaeid prawns) (Bell et al. 1978) and cryptic skin colouration for camouflage over surficial sediments with varying proportions of mud. The importance of soft sediments for predator evasion has been demonstrated by Gibson \& Robb (2000), who showed that juvenile plaice Pleuronetes platessa consistently selected the finest sediments that facilitated rapid burial. Sediment composition was also important for penaeid prawns. For instance, although amount of seagrass habitat in the landscape explained most of the variation in prawn density, Metapenaeus bennettae was influenced more by short-leaved seagrasses and sandy sediments, whilst Penaeus plebejus was influenced more by long-leaved seagrasses with muddier sediments. Laboratory experiments (Masel \& Smallwood 2000) on juvenile $M$. bennettae support the refuge function offered by seagrasses, although distributions of free-ranging prawns suggest that this species does not have an obligate relationship with seagrasses (Halliday 1995). Sediment preferences have often been observed for penaeids, and several reasons are thought to account for this, including: (1) availability of food, (2) problems associated with respiring when buried, (3) ease of burrowing, and (4) recognition of substratum that is likely to exhibit high densities of conspecifics (Dall et al. 1990).

\section{Importance of life history}

Path analysis for small-bodied resident species explained substantially more variation (45 to $70 \%$ ) than for larger bodied and broader ranging generalists $(<20 \%)$. The differences in explanatory power of path models are best understood from the examination of species differences in biological characteristics including life history, which determine the types of resources that can be used effectively (Hansen \& Urban 1992) and the characteristic scales at which a species or life stage will respond to variability in its environment. For instance, broad-ranging transient species have lifecycle trajectories that extend beyond the spatial and temporal scales of this study and, as such, are less likely to respond to the heterogeneity measured here. The density of Sillago spp. was poorly explained by substratum structure at any of the spatial scales in this study. These fish are widely distributed generalists with fast-swimming demersal juveniles and adults that readily move across a wide range of substratum types. Furthermore, seasonal patterns in the use of inshore areas, as well as spatial patchiness in distribution as a result of schooling behaviour, increase variance, leading to an overall lowering of the explanatory power. In contrast, resident strategists such as gobies may be present all year round in inshore waters, with less distinct temporal fluctuations. Gobies are epibenthic and considerably less mobile, with smaller home ranges and are more likely to have specialist preferences and thus respond to local environmental variability. The numerically dominant species using vegetated tidal 
flats were anatomically, physiologically and behaviourally adapted for utilisation of seagrass beds, and have been considered as seagrass-associated or seagrass-resident species. For these species, within-patch variables of plant and surficial sediment structure made a much greater contribution to the explanation of variation in density than for the most abundant of the species that used mangroves at high tide.

Life-history strategies and traits may represent a mechanism underlying broader patterns in the way that inshore marine landscapes are utilised, and may be useful in guiding management strategies and predicting sensitivity to change (Hansen \& Urban 1992). Species with similar biological characteristics (i.e. lifehistory strategies and tactics) will respond more similarly to variability in the environment and at similar scales than would species with very different characteristics. For other animal groups, such as birds, linkages also have been identified between life-history traits and response to specific landscape features (Hansen \& Urban 1992, McAlpine et al. 2002).

\section{Limitations of the study}

A key limitation of this study, with regard to the selection of an organism-scaled spatial extent, was the absence of any quantitative data on individual movement patterns in time and space. In fact, as the research progressed sampling in subtidal areas revealed that fish and prawns did not concentrate in shallow subtidal water as was originally assumed, with many animals moving during daily tidal excursions over greater distances than the landscape units examined in this study (100 and $300 \mathrm{~m}$ radii). However, broader spatial extents would have resulted in high spatial overlap in the buffer areas, and the inclusion of large proportions of adjacent land, particularly for samples collected in the upper intertidal areas. Nevertheless, future studies could usefully include a broader range of spatial extents, which may lead to the identification of an optimal spatial scale. The importance of mapping movement patterns for the purpose of scale selection has been discussed by Pittman \& McAlpine (2003). In addition, it is important to understand that the results shown here refer predominantly to juveniles and that adults may exhibit different space use patterns and thus respond to an entirely different suite of environmental variables than those presented here.

\section{CONCLUSIONS}

We conclude that a hierarchical landscape approach is appropriate for the study of marine animals, and advocate a wider use of such an approach in marine ecology. This requires that benthic structure at multiple spatial scales, including landscape composition and configuration, should be considered in any attempt to explain variation in marine faunal species density and assemblage composition. A shift in focus for marine ecologists and resource managers that encompasses landscape structure is necessary in attempts to comparatively evaluate the importance of inshore areas for biodiversity and fisheries and, more broadly, for the development of marine protection legislation and resource management strategies, public education and research. For instance, it is realistic to expect that a large proportion of the difference in fish density between an impacted site and a control site could be explained by differences in the surrounding landscape structure. For heavily exploited species, appropriately scaled information may be crucial if populations are to be maintained or enhanced. Furthermore, the size, shape and geographic prioritisation of management strategies such as reserves or marine parks must be driven, not just by the identification of essential habitat for processes such as nursery function and spawning, but also by including information on the spatial arrangement of these areas in relation to one another and on the likely influence of differing landscape mosaic structures on utilisation patterns. For example, an appropriate future research question might be: How does the amount and spatial arrangement of neighbouring seagrasses and mangroves influence coral reef fish populations? Studies that focus on structural and functional connectivity between component habitat types will provide important ecological information that will contribute to the development of a hierarchical landscape approach to marine resource management.

Acknowledgements. We thank S. Bell, R. Kneib and 4 anonymous reviewers for their valuable comments. This work was supported by an International Postgraduate Research Scholarship from the Commonwealth Government of Australia and a University of Queensland International Postgraduate Research Scholarship from the University of Queensland, both awarded to S.J.P.

\section{LITERATURE CITED}

Acosta CA (1999) Benthic dispersal of Caribbean spiny lobsters among insular habitats: implications for the conservation of exploited marine species. Conserv Biol 13(3): $603-612$

Addicott JF, Aho JM, Antolin MF, Padilla DK, Richardson JS, Soluk DA (1987) Ecological neighborhoods: scaling environmental patterns. Oikos 49:340-346

Akaike H (1973) Information theory and an extension of the maximum likelihood principle. In: Petrov BN, Csaki F (eds) International symposium on information theory. Akademiai Kiado, Budapest, p 267-281 
Allen TFH, Hoekstra TW (1992) Toward a unified ecology. Columbia University Press, New York

Allen TFH, Starr TB (1982) Hierarchy: perspectives for ecological diversity. University of Chicago Press, Chicago, IL

Andrén H (1994) Effects of habitat fragmentation on birds and mammals in landscapes with different proportions of suitable habitat: a review. Oikos 75:355-366

Attrill MJ, Strong JA, Rowden AA (2000) Are macroinvertebrate communities influenced by seagrass structural complexity? Ecography 23:114-121

Belbin L (1991) Semi-strong hybrid scaling, a new ordination algorithm. J Veg Sci 2:491-496

Belbin L (1995) PATN pattern analysis package. CSIRO Division of Wildlife and Ecology, Lyneham

Belbin L, McDonald C (1993) Comparing three classification strategies for use in ecology. J Veg Sci 4:341-348

Belbin L, Faith DP, Milligan GW (1992) A comparison of two approaches to beta-flexible clustering. Multivariate Behav Res 27(3):417-433

Bell JD, Westoby M (1986a) Importance of local changes in leaf height and density to fish and decapods associated with seagrasses. J Exp Mar Biol Ecol 104:249-274

Bell JD, Westoby M (1986b) Variation in seagrass height and density over a wide spatial scale: effects on fish and decapods. J Exp Mar Biol Ecol 104:275-295

Bell JD, Burchmore JJ, Pollard DA (1978) Feeding ecology of a scorpaenid fish, the fortescue Centropogon australis, from a Posidonia seagrass habitat in New South Wales. Aust J Mar Freshw Res 29:175-185

Bell SS, Brooks RA, Robbins BD, Fonseca MS, Hall MO (2001) Faunal response to fragmentation in seagrass habitats: implications for seagrass conservation. Biol Conserv 100: 115-123

Birkeland C (1985) Ecological interactions between mangroves, seagrass beds and coral reefs. In: Birkeland $C_{\text {, }}$ Grosenbaugh D (eds) Ecological interactions between tropical coastal ecosystems. UNEP Reg Seas Rep Stud 73: $1-26$

Blaber SJM, Blaber TG (1980) Factors affecting the distribution of juvenile estuarine and inshore fish. J Fish Biol 17(2):143-162

Bray JR, Curtis JT (1957) An ordination of the upland forest communities of southern Wisconsin. Ecol Monogr 27:325349

Cocheret de la Morinière E, Pollux BJA, Nagelkerken I, Hemminga MA, Huiskes AHL, van der Velde G (2003) Ontogenetic dietary changes of coral reef fishes in the mangrove-seagrass-reef continuum: stable isotopes and gut-content analysis. Mar Ecol Prog Ser 246:279-289

Cocheret de la Morinière E, Nagelkerken I, van der Meij H, van der Velde G (2004) What attracts juvenile coral reef fish to mangroves: habitat complexity or shade? Mar Biol 144:139-145

Connolly RM (1994) Comparison of fish catches from a buoyant pop net and a beach seine net in a shallow seagrass habitat. Mar Ecol Prog Ser 109:305-309

Connolly RM, Butler AJ (1996) The effects of altering seagrass canopy height on small, motile invertebrates of shallow Mediterranean embayments. PSZN I: Mar Ecol 17(4): $637-652$

Connor EF, McCoy ED (1979) The statistics and biology of the species-area relationship. Am Nat 113:791-833

Crist TO, Guertin DS, Wiens JA, Milne BT (1992) Animal movement in heterogeneous landscapes: an experiment with Eleodes beetles in shortgrass prairie. Funct Ecol 6: 536-544

Cushman SA, McGarigal K (2002) Landscape-level patterns of avian diversity in the Oregon coast range. Ecol Monogr 73(2):259-281

Dall W, Hill BJ, Rothlisberg PC, Sharples DJ (1990) The biology of the Penaeidae. Adv Mar Biol 27:1-489

Dunning JB, Danielson BJ, Pulliam HR (1992) Ecological processes that affect populations in complex landscapes. Oikos 65:169-175

Eggleston DB (1999) Application of landscape ecological principles to oyster reef habitat restoration. In: Luckenbach MW, Mann R, Wesson JA (eds) Oyster reef habitat restoration: a synopsis and synthesis of approaches. Virginia Institute of Marine Science Press, Gloucester Point, VA, p 213-227

Fahrig L (1997) Relative effects of habitat loss and fragmentation on population extinction. J Wildl Manage 61:603-610

Fahrig L (1998) When does fragmentation of breeding habitat affect population survival? Ecol Model 105:273-292

Fahrig L (2002) Effect of habitat fragmentation on the extinction threshold: a synthesis. Ecol Appl 12:346-353

Fahrig L (2003) Effects of habitat fragmentation on biodiversity. Annu Rev Ecol Evol Syst 34:487-515

Flather $\mathrm{CH}$, Bevers M (2002) Patchy reaction-diffusion and population abundance: the relative importance of habitat amount and arrangement. Am Nat 159:40-56

Garrabou J, Riera J, Zabala M (1998) Landscape pattern indices applied to Mediterranean subtidal rocky benthic communities. Landsc Ecol 13:225-247

Gibson RN, Robb L (2000) Sediment selection in juvenile plaice and its behavioural basis. J Fish Biol 56(5):1258-1275

Gill HS, Potter IC (1993) Spatial segregation amongst goby species within an Australian estuary, with a comparison of the diets and salinity tolerance of the two most abundant species. Mar Biol 117(3):515-526

Gillanders BM, Able KW, Brown JA, Eggleston DB, Sheridan PF (2003) Evidence of connectivity between juvenile and adult habitats for mobile marine fauna: an important component of nurseries. Mar Ecol Prog Ser 247:281-295

Grand J, Cushman SA (2003) A multi-scale analysis of species-environment relationships: breeding birds in a pitch pine-scrub oak (Pinus rigida-Quercus ilicifolia) community. Biol Conserv 112:307-317

Green EP, Edwards AJ, Clark CD (2000) Remote sensing handbook for tropical coastal management. UNESCO Publishing, Paris

Gustafson EJ (1998) Quantifying landscape spatial pattern: What is the state of the art? Ecosystems 1:143-156

Haines-Young R, Chopping M (1996) Quantifying landscape structure: a review of landscape indices and their application to forested landscapes. Prog Phys Geogr 20(4):418-445

Halliday IA (1995) Influence of natural fluctuations in seagrass cover on commercial prawn nursery grounds in a subtropical estuary. Mar Freshw Res 46(8):1121-1126

Hansen AJ, Urban DL (1992) Avian response to landscape pattern: the role of species' life histories. Landsc Ecol 7(3): $163-180$

Hargis CD, Bissonette JA, David JL (1998) The behaviour of landscape metrics commonly used in the study of habitat fragmentation. Landsc Ecol 13:167-186

Harmelin-Vivien ML, Francour P (1992) Beam trawling or visual census? Methodological bias in the assessment of fish populations in seagrass beds. PSZN I: Mar Ecol 13: $41-51$

Heck KL, Orth RJ (1980) Seagrass habitats: the roles of habitat complexity, competition and predation in structuring associated fish and motile macro-invertebrate assemblages. In: Kennedy VS (ed) Estuarine perspectives. Academic Press, New York, p 449-464 
Hindell JS, Jenkins GP, Keough MJ (2000) Variability in abundance of fishes associated with seagrass habitats in relation to diets of predatory fishes. Mar Biol 136:725-737

Holling CS (1992) Cross-scale morphology, geometry and dynamics of ecosystems. Ecol Monogr 62:447-502

Holling CS (1998) Two cultures of ecology. Conserv Ecol 2(2): 4. Available at www.consecol.org/vol2/iss2/art4; INTERNET

Holt SA, Kitting CL, Arnold CR (1983) The distribution of young red drums among different seagrass meadows. Trans Am Fish Soc 112:267-271

Hovel KA, Fonseca MS, Myer DL, Kenworthy WJ, Whitfield PE (2002) Effects of seagrass landscape structure, structural complexity and hydrodynamic regime on macrofaunal densities in North Carolina seagrass beds. Mar Ecol Prog Ser 243:11-24

Irlandi EA (1994) Large and small-scale effects of habitat structure on rates of predation: how percent coverage of seagrass affects rates of predation and siphon nipping on an infaunal bivalve. Oecologia 98:176-183

Irlandi EA, Crawford MK (1997) Habitat linkages: the effect of intertidal saltmarshes and adjacent subtidal habitats on abundance, movement and growth of an estuarine fish. Oecologia 110:222-230

Irlandi EA, Ambrose WG, Orlando BA (1995) Landscape ecology and the marine environment: how spatial configuration of seagrass habitat influences growth and survival of the bay scallop. Oikos 72(3):307-313

Jonsen ID, Fahrig L (1997) Response of generalist and specialist insect herbivores to landscape spatial stucture. Landsc Ecol 12:185-197

Kneib RT (1994) Spatial pattern, spatial scale and feeding in fishes. In: Stouder DJ (ed) Theory and application in fish feeding ecology. University of South Carolina Press, Columbia, SC, p 171-185

Kotliar NB, Wiens JA (1990) Multiple scales of patchiness and patch structure: a hierarchical framework for the study of heterogeneity. Oikos 59:253-260

Laegdsgaard P, Johnson C (2001) Why do juvenile fish utilise mangrove habitats? J Exp Mar Biol Ecol 257:229-253

Lee M, Fahrig L, Freemark K, Currie DJ (2002) Importance of patch scale vs landscape scale on selected forest birds. Oikos 96:110-118

Levin SA (1992) The problem of pattern and scale in ecology. Ecology 73(6):1943-1967

Loehle C, Wein G (1994) Landscape habitat diversity: a multiscale information-theory approach. Ecol Model 73(3-4): 311-329

Lui J, Taylor WW (2002) Integrating landscape ecology into natural resource management. Cambridge University Press, Cambridge

Mackey BG, Lindenmayer DB (2001) Towards a hierarchical framework for modelling the spatial distribution of animals. J Biogeogr 28:1147-1166

Marguillier S, van der Velde G, Dehairs F, Hemminga MA, Rajagopal S (1997) Trophic relationships in an interlinked mangrove-seagrass ecosystem as traced by $\delta^{13} \mathrm{C}$ and $\delta^{15} \mathrm{~N}$. Mar Ecol Prog Ser 151:115-121

Masel JM, Smallwood DG (2000) Habitat usage by postlarval and juvenile prawns in Moreton Bay, Queensland, Australia. Proc R Soc Qld 109:107-117

McAlpine CA, Eyre TJ (2002) Testing landscape metrics as indicators of habitat loss and fragmentation in continuous eucalyptus forests (Queensland, Australia). Landsc Ecol 17(8):711-728

McAlpine CA, Grigg GC, Mott JJ, Sharma P (1999) Influence of landscape structure on kangaroo abundance in a dis- turbed semi-arid woodland of Queensland. Rangeland J 21(1):104-134

McAlpine CA, Lindenmayer DB, Eyre TJ, Phinn SP (2002) Landscape surrogates of forest fragmentation: synthesis of Australian Montreal Process case studies. Pac Conserv Biol 8:108-120

McArthur RH (1965) Pattern of species diversity. Biol Rev 40: 510-533

McArthur RH, Wilson EO (1967) The theory of island biogeography. Princeton University Press, Princeton, NJ

McCoy ED, Bell SS (1991) Habitat structure: the evolution and diversification of a complex topic. In: Bell SS, McCoy ED, Mushinsky HR (eds) Habitat structure: the physical arrangement of objects in space. Chapman and Hall, New York, p 3-27

McDonald RP, Marsh HW (1990) Choosing a multivariate model: noncentrality and goodness of fit. Psychol Bull 107: $247-255$

McGarigal K, Marks BJ (1994) FRAGSTATS, spatial pattern analysis program for quantifying landscape structure, v2.0. Forest Science Department, Oregon State University, Corvallis, OR

McGarigal K, McComb WC (1995) Relationships between landscape structure and breeding birds in the Oregon coast range. Ecol Monogr 65(3):235-260

McIvor CC, Odum WE (1988) Food, predation risk and microhabitat selection in a marsh fish assemblage. Ecology 69(5):1341-1351

McNeill SE, Bell JD (1992) Comparison of beam trawls for sampling macrofauna of Posidonia seagrass. Estuaries 15: 360-367

McNeill SE, Fairweather PG (1993) Single large or several small marine reserves? An experimental approach with seagrass fauna. J Biogeogr 20:429-440

Micheli F, Peterson CH (1999) Estuarine vegetated habitats as corridors for predator movements. Conserv Biol 13(4): 869-881

Mitchell RJ (1992) Testing evolutionary and ecological hypotheses using path analysis and structural equation modelling. Funct Ecol 6:123-129

Morris DW (1987) Ecological scale and habitat use. Ecology 68(2):362-369

Mumby PJ (2001) Beta and habitat diversity in marine systems: a new approach to measurement, scaling and interpretation. Oecologia 128(4):274-280

Mumby PJ, Harbourne AR (1999) Development of a systematic classification scheme of marine habitats to facilitate regional management and mapping of Caribbean coral reefs. Biol Conserv 88:155-163

Mumby PJ, Edwards AJ, Arias-González J, Lindeman KC and 8 others (2004) Mangroves enhance the biomass of coral reef fish communities in the Caribbean. Nature 427:533-536

Nagelkerken I, Dorenbosch M, Verberk W, Cocheret de la Morinière E, van der Velde G (2000) Importance of shallow-water biotopes of a Caribbean bay for juvenile coral reef fishes: patterns in biotope association, community structure and spatial distribution. Mar Ecol Prog Ser 202: $175-192$

Nagelkerken I, Kleijnen S, Klop T, van den Brand RACJ, Cocheret de la Morinière E, van der Velde G (2001) Dependence of Caribbean reef fishes on mangroves and seagrass beds as nursery habitats: a comparison of fish faunas between bays with and without mangroves/seagrass beds. Mar Ecol Prog Ser 214:225-235

Ogden JC, Gladfelter EH (eds) (1983) Coral reefs, seagrass beds and mangroves: their interaction in the coastal zones of the Caribbean. UNESCO Rep Mar Sci 23:1-133 
O'Neill RV, DeAngelis DL, Waide JB, Allen TFH (1986) A hierarchical concept of ecosystems. Princeton University Press, Princeton, NJ

Orth RJ (1992) A perspective on plant-animal interactions in seagrasses: physical and biological determinants influencing plant and animal abundance. In: John DM, Hawkins SJ, Price JH (eds) Plant-animal interactions in the marine benthos. Systematics Association Special Volume No 46. Clarendon Press, Oxford, p 147-164

Orth RJ, Heck Jr KL, van Montfrans J (1984) Faunal relationships in seagrass beds: a review of the influence of plant structure and prey characteristics. Estuaries 7:339-350

Parrish JD (1989) Fish communities of interacting shallowwater habitats in tropical oceanic regions. Mar Ecol Prog Ser 58:143-160

Pearson SM (1993) The spatial extent and relative influence of landscape-level factors on wintering bird populations. Landsc Ecol 8(1):3-18

Pittman SJ, McAlpine CA (2003) Movement of marine fish and decapod crustaceans: process, theory and application. Adv Mar Biol 44:205-294

Ricklefs RE (1987) Community diversity: relative roles of local and regional processes. Science 235:167-171

Robbins BD, Bell SS (1994) Seagrass landscapes: a terrestrial approach to the marine environment. Trends Ecol Evol 9(8):301-304

Rönnbäck P, Troell M, Kautsky N, Primavera JH (1999) Distribution pattern of shrimps and fish among Avicennia and Rhizophora microhabitats in the Pagbilao mangroves, Philippines. Estuar Coast Shelf Sci 48:223-234

Sale PF (1998) Appropriate spatial scales for studies of reeffish ecology. Aust J Ecol 23:202-208

Salita JT, Ekau W, Saint-Paul U (2003) Field evidence on the influence of seagrass landscapes on fish abundance in Bolinao, northern Philippines. Mar Ecol Prog Ser 247:183-195

Sanchez-Jerez P, Gillanders BM, Kingsford MJ (2002) Spatial variation in abundance of prey and diet of trumpeter (Pelates sexlineatus: Teraponidae) associated with Zostera capricorni seagrass meadows. Aust Ecol 27(2):200-210

Schlosser IJ (1995) Critical landscape attributes that influence fish population dynamics in headwater streams. Hydrobiologia 303:71-81

Schmiegelow FKA, Mönkkönen M (2002) Fragmentation issues in dynamic landscapes: avian perspectives from the boreal forest. Ecol Appl 12:375-389

Schneider DC (2001) The rise of the concept of scale in ecology. Bioscience 51(7):545-553

Serafy JE, Harrell RM, Stevenson JC (1988) Quantitative sampling of small fishes in dense vegetation: design and field testing of portable 'pop-nets'. J Appl Ichthyol 4:149-157

Sheppard CRC, Matheson K, Bythell JC, Murphy P, Myers CB, Blake B (1995) Habitat mapping in the Caribbean for management and conservation: use and assessment of aerial photography. Aquat Conserv 5:277-298

Shipley B (1997) Exploratory path analysis with applications in ecology and evolution. Am Nat 149(6):1113-1138

Editorial responsibility: Otto Kinne (Editor), Oldendorf/Luhe, Germany
Shipley B (2000) Cause and correlation in biology: a users guide to path analysis, structural equations and causal inference. Cambridge University Press, Cambridge

Sokal RR, Rohlf FJ (1995) Biometry. Freeman and Company, San Francisco, CA

Southwood TRE (1977) Habitat, the templet for ecological strategies? J Anim Ecol 46:337-365

Steiger JH (1995) Structural equation modelling. In: STATISTICA for Windows, Vol III: Statistics II. StatSoft Inc, Tulsa, OK, p 3545-3688

Tanaka JS, Huba GJ (1989) A general coefficient of determination for covariance structure models under arbitrary GLS estimation. Br J Math Stat Psychol 42:233-239

Trzcinski MK, Fahrig L, Merriam G (1999) Independent effects of forest cover and fragmentation on the distribution of forest breeding birds. Ecol Appl 9:586-593

Tscharntke T, Steffan-Dewenter I, Kruess A, Theis C (2002) Contribution of small habitat fragments to conservation of insect communities of grassland-cropland landscapes. Ecol Appl 12:354-366

Turner MG (1989) Landscape ecology: the effect of pattern on process. Annu Rev Ecol Syst 20:171-197

Turner SJ, Hewitt JE, Wilkinson MR, Morries DJ, Thrush SF, Cummings VJ, Funnell G (1999) Seagrass patches and landscapes: the influence of wind wave dynamics and hierarchical arrangement of spatial structure on macrofaunal seagrass communities. Estuaries 22:1016-1032

Urban DL, O'Neill RV, Shugart HH (1987) Landscape ecology: a hierarchical perspective can help scientists understand spatial patterns. Bioscience 37(2):119-127

Villard M-A, Trzcinski MK, Merriam G (1999) Fragmentation effects on forest birds: relative influence of woodland cover and configuration on landscape occupancy. Conserv Biol 13(4):774-783

Warburton K, Blaber SJM (1992) Patterns of recruitment and resource use in a shallow-water fish assemblage in Moreton Bay, Queensland. Mar Ecol Prog Ser 90: $113-126$

Ward TJ, Vanderklift MA, Nicholls AO, Kenchington RA (1999) Selecting marine reserves using habitats and species assemblages as surrogates for biological diversity. Ecol Appl 9:691-698

Wiens JA (1995) Landscape mosaics and ecological theory. In: Hansson L, Fahrig L, Merriam G (eds) Mosaic landscapes and ecological processes. Chapman and Hall, London, p 1-26

Wiens JA, Milne BT (1989) Scaling of 'landscapes' in landscape ecology, or, landscape ecology from a beetle's perspective. Landsc Ecol 3(2):87-96

With KA, Crist TO (1995) Critical thresholds in species' responses to landscape structure. Ecology 76:2446-2459

Wooton JT (1994) Predicting direct and indirect effects: an integrated approach using experiments and path analysis. Ecology 75(1):151-165

Wright S (1921) Correlation and causation. J Agric Res 20(7): $557-585$

Submitted: February 17, 2004; Accepted: July 27, 2004

Proofs received from author(s): November 8, 2004 